OPEN ACCESS

Edited by:

Lu-Jun Li,

Chinese Academy of Science, China

Reviewed by:

Joseph E. Knelman,

University of Colorado Boulder,

United States

Su Xukun,

Research Center for

Eco-Environmental

Sciences (CAS), China

*Correspondence:

Simone Ravetto Enri

simone.ravettoenri@unito.it

${ }^{+}$These authors have contributed equally to this work

Specialty section: This article was submitted to

Soil Processes,

a section of the journal

Frontiers in Environmental Science

Received: 09 October 2020 Accepted: 14 December 2020

Published: 19 January 2021

Citation:

Mainetti A, D'Amico M, Probo M, Quaglia E, Ravetto Enri S, Celi L and

Lonati M (2021) Successional

Herbaceous Species Affect Soil Processes in a High-Elevation Alpine

Proglacial Chronosequence.

Front. Environ. Sci. 8:615499.

doi: 10.3389/fenvs.2020.615499

\section{Successional Herbaceous Species Affect Soil Processes in a High-Elevation Alpine Proglacial Chronosequence}

\author{
Andrea Mainetti ${ }^{1}$, Michele D'Amico ${ }^{1}$, Massimiliano Probo ${ }^{2}$, Elena Quaglia ${ }^{1}$, \\ Simone Ravetto Enri ${ }^{1 *}$, Luisella Celi ${ }^{1+}$ and Michele Lonati ${ }^{1+}$ \\ ${ }^{1}$ Department of Agricultural, Forest and Food Sciences, University of Torino, Grugliasco, Italy, ${ }^{2}$ Agroscope, Grazing Systems, \\ Nyon, Switzerland
}

The study investigated plant-soil interactions along a proglacial chronosequence in the Italian Alps, with a specific focus on pioneer and grassland species structure and biogeochemical processes, with the aim to evaluate the biotic patterns in ecosystem development. We recorded vascular plant frequencies and the mean diameter of one pioneer and one grassland target species in 18 permanent plots distributed along six different stages encompassing a 170-years chronosequence in the Lauson Glacier forefield (NW Italy). We evaluated the main soil properties and measured the C:N:P stoichiometry in the biomass of pioneer and grassland target species and in the underlying soil. For comparative purposes, we analyzed also bare soils sampled near the sampled plant individuals. Pioneer species number and cover significantly increased 10 and 40 years after deglaciation respectively, while alpine grassland species cover and number peaked only after 65 and 140 years, respectively. Along the chronosequence, soils beneath vascular plants were enriched in nutrients, especially under individuals of alpine grassland species, with total organic $C$ contents ranging between 1.3 and $8.9 \mathrm{~g} \cdot \mathrm{kg}^{-1}$ compared to 0.2 and $3.3 \mathrm{~g} \cdot \mathrm{kg}^{-1}$ in bare soils. Nitrogen content in bare soils was nearly undetectable, while it increased in the plant-affected soils, leading to a more balanced C: $\mathrm{N}$ : $\mathrm{P}$ stoichiometry in the oldest stages. The colonization of alpine grassland species started immediately, although species number and cover increased only when the soil acquired sufficient nutrient supply and functionality. Although the ecosystem remained $\mathrm{C}$ and $\mathrm{N}$ limited, the soil could provide adequate conditions for more competitive species establishment, as confirmed by the increasing number and cover of alpine grassland species. Thus, soil nutrient dynamics were strongly influenced by plants, with a major influence triggered by late-successional grassland species.

Keywords: biotic and abiotic processes, carbon, nitrogen, phosphorus, plant-soil interaction 


\section{INTRODUCTION}

Throughout the last 170 years, the alpine region has been affected by an enhanced glacier retreat, with the exception of limited periods of glacier advance (Dyurgerov and Meier, 2000; Pörtner et al., 2019). This phenomenon accelerated at historically unprecedented rates during the last few decades, with alpine glaciers that have already lost nearly $50 \%$ of their total surface area since 1850 (Paul et al., 2004; Zemp et al., 2006). Consequently, new ice-free surfaces can nowadays provide the opportunity to investigate primary successions, soil development and emerging patterns of ecosystem structure and functions (Matthews, 1992; Egli et al., 2010).

The glacier retreat modifies the hydrological response and the sediment transport within glacier-covered basins, while the newice-free areas are destabilized by paraglacial processes. Mineral substrate left free from ice lacks in biological materials and the net primary production is limited by extreme abiotic constraints, such as low temperatures, intense solar irradiation and strong temperature variations (Stöcklin and Bäumler, 1996; Vitousek et al., 1997; Jones and del Moral, 2009). Receding glaciers open up surfaces for the succession of biota, which protects the released detritus. In turn, the stabilized till supports storage and interception of water and elements that allow plant colonization and soil development (Matthews, 1992; Matthews, 1999; Walker and del Moral, 2003). The combination of these abiotic and biotic processes and their interactions change with time since deglaciation, creating unique chronosequences (Egli et al., 2001; Cannone et al., 2008; Eichel, 2019), characterized by a short space-for-time substitution, from young, recently deglaciated debris to the oldest moraines (Pickett, 1989). Time since deglaciation is indeed assumed to be the key driver for ecosystem development, even though local processes at a small scale are not always negligible (Burga et al., 2010; Dümig et al., 2011).

One of the typical vegetation dynamics in these environments leads to species replacement along successional stages, from pioneer to early, mid- and late-successional species, where the latter are typical alpine grassland species, above treeline (Eichel, 2019). In order to identify successional trajectories and biodiversity dynamics, the correct attribution of the ecological needs to the species is essential, based on phytosociological findings or species traits. Grouping species in functional pools and evaluating their patterns along a chronosequence can provide a more comprehensive interpretation of vegetation dynamics and an easier tool for comparative community ecology (Caccianiga and Andreis, 2004). Additionally, the study of species traits, such as demographic structure of target species belonging to different successional stages (i.e., pioneer or late-successional species) or Competitor, Stress-tolerator, Ruderal (CSR) strategies (Grime, 2006), can allow deep insights into the reproductive mechanisms or the community interactions such as facilitation (Caccianiga et al., 2006; Těšitel et al., 2014).

The progressive plant colonization of high-altitude environments leads to soil formation, including mineral weathering (Mavris et al., 2010; Bernasconi et al., 2011), changes in microbial communities (Nemergut et al., 2007;
Jumpponen et al., 2012), carbon (C) accumulation and nutrient cycling, especially nitrogen $(\mathrm{N})$ and phosphorus $(\mathrm{P})$ (Egli et al., 2006; Bernasconi et al., 2011). The combination of pedogenic processes with the $\mathrm{C}: \mathrm{N}: \mathrm{P}$ stoichiometry in the soilmicroorganisms-plant system can furnish key information for understanding the ecological relationships between plant communities and nutritional requirements. In particular, pioneer communities can play an essential role in the kick-off of soil biogeochemical processes, while late-successional ones exert a stronger influence on nutrient dynamics (Matthews 1992). It should be further noticed that, in high altitude primary successions, the effect of single herbaceous species may be easily identified, because of the low and discontinuous vegetation cover. Bonanomi et al. (2016), for instance, described the effect of single plants of Silene acaulis on soil C and N contents along an altitudinal gradient, proving its beneficial effects compared to soil without vegetation.

Soil nutrient dynamics and ecosystem development may in turn drive the C:N:P stoichiometry in photosynthetic tissues (Sardans et al., 2012; Zhang et al., 2018). If C and $\mathrm{N}$ generally remain the limiting factors in alpine ecosystems (Körner, 2003), in proglacial environments, the short spatial-temporal span can lead to faster changes in C:N:P patterns in plant species, although nutrient limitation and co-limitation in these environments are still poorly understood. However, a comprehensive approach which encompasses functional species pool cover and successional single species dynamics with soil biogeochemistry still remains largely unknown in high-altitude proglacial chronosequences.

Based on these considerations, we hypothesized that the succession and the related actions of plant species occurring in a short spatial-temporal span since deglaciation play a pivotal role for soil formation and development, leading to favourable ecological conditions for progressively hosting more competitive species. Thus, this study aimed at evaluating pioneer and late-successional grassland species patterns and their role in soil development and nutrient biogeochemistry along a high-altitude proglacial chronosequence in the western Italian Alps (Lauson glacier). To deeply understand the soil-plant interplayed relationship, we further investigated the role of two herbaceous single species in nutrient dynamics, i.e., the pioneer Saxifraga oppositifolia L. subsp. glandulifera Vacc. (hereafter Saxifraga) and the late-successional S. acaulis (L.) Jacq subsp. bryoides (Jord.) Nyman (hereafter Silene).

\section{MATERIALS AND METHODS}

\section{Study Area}

The study was carried out in the proglacial foreland of the Lauson glacier, a small glacier with a $0.23 \mathrm{~km}^{2}$ surface and $700 \mathrm{~m}$ length (Smiraglia and Diolaiuti, 2015; Figure 1), located within Gran Paradiso National Park (SAC/SPA IT1201000) in the upper Cogne Valley (Aosta Valley Region, North-Western Italy). The considered proglacial foreland was between the glacier terminus in 2016 and the frontal moraines left around 1820 during the Little Ice Age, located at 3,030 and 2,750 $\mathrm{m}$ a.s.l., 


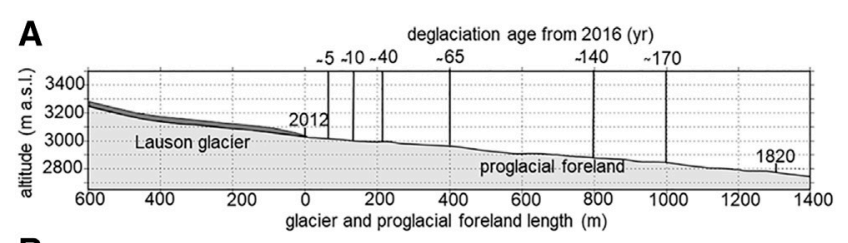

B

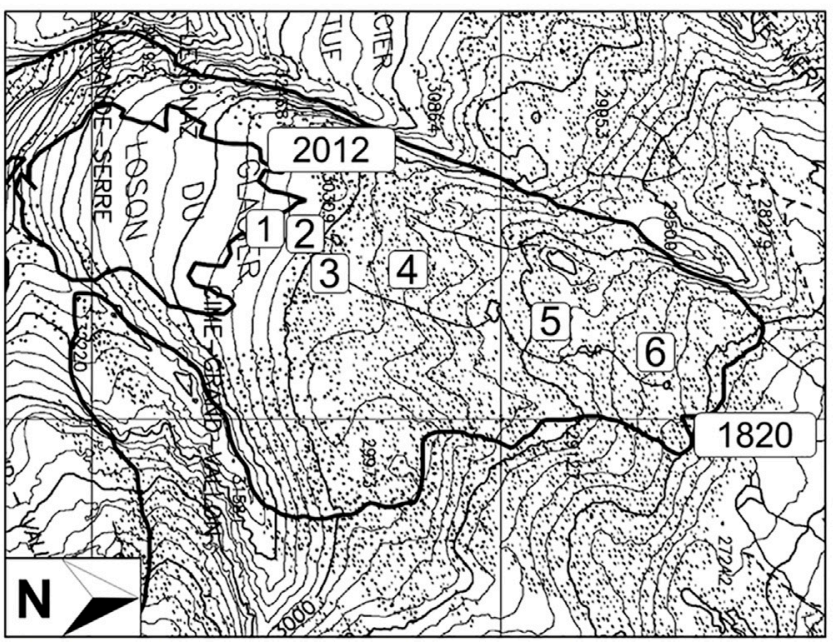

C

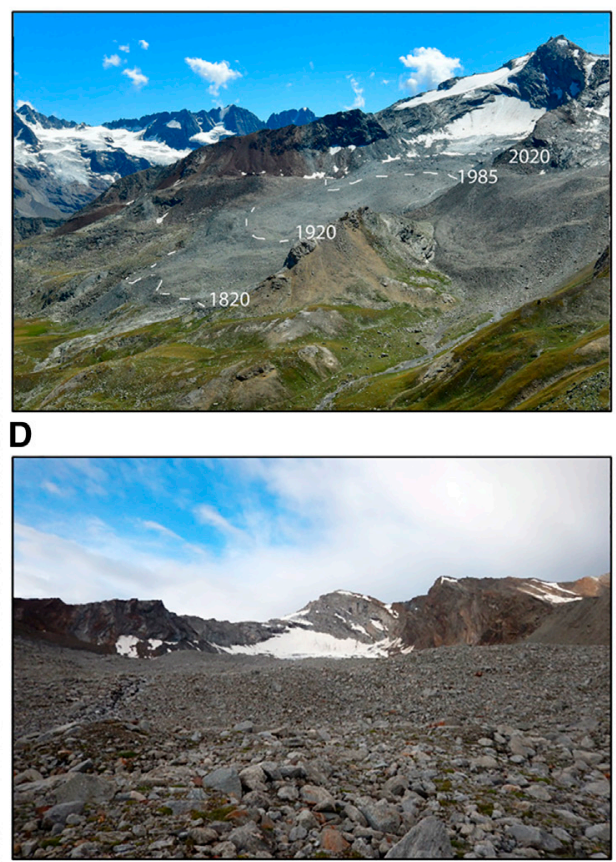

FIGURE 1 | Representation of the Lauson glacier foreland: elevation profile (A) including the limits of the reconstructed glacier retreat (1820-2012) and the age from deglaciation of the six stages of the chronosequence; Regional Technical Map (B) with the positions of the stages of the chronosequence and the glacier terminus in 2012 and 1820; photo of the study area (C) with drawing of four known historical glacier terminus; photo of the oldest stage (D) deglaciated for ca. 170 years.

respectively. The linear distance between the two moraines is $1,300 \mathrm{~m}$, with a surface of about $0.65 \mathrm{~km}^{2}$. The climate of the Cogne Valley is endalpic, with mean annual precipitation of about $700 \mathrm{~mm}$ and mean annual temperature of $+4.1^{\circ} \mathrm{C}$ (mean values of Valnontey and Lillaz weather stations, at $1700 \mathrm{~m}$ a.s.l.). The proglacial foreland is usually covered by snow between October and mid-July, and it has mean annual temperatures between -1 and $-3^{\circ} \mathrm{C}$ (Mercalli and Berro, 2003). The soils are Eutric Skeletic Regosols (IUSS Working Group WRB, 2015), characterized by homogeneous texture and parent rock composition (mainly paragneiss with small quantities of amphibolites, Le Bayon and Ballevre, 2006), with disturbances limited to cryoturbation, solifluction and a weak water erosion. The vegetation is mainly composed of sparse individuals of alpine pioneer and grassland species, such as S. oppositifolia, Artemisia genipi Weber ex Stechm., S. acaulis and Poa alpina L. Out of the proglacial area, the climax vegetation is alpine grassland, dominated by Carex curvula All. The potential treeline in the area is around 2,350 $\mathrm{m}$ a.s.l. (Pecher et al., 2011). Climax soils under the climax alpine prairie are Skeletic Umbrisols or Skeletic Dystric Cambisols (IUSS Working Group WRB, 2015; D’Amico et al., 2020a).

We retraced the retreat of the proglacial terminus since 1820 until 2016 by analyzing historical field surveys carried out by the Istituto Geografico Militare in 1820, 1882, and 1931 and by performing photointerpretation of Regional Technical Maps (1975), ortophotos (1999, 2005, 2012), and SPOT satellite images (2009) (SctGeoVdA, 2020). A six stage chronosequence
TABLE 1 | Description of the identified chronosequence stages.

\begin{tabular}{lcccc}
$\begin{array}{l}\text { Chronosequence } \\
\text { stage }\end{array}$ & $\begin{array}{c}\text { Deglaciation } \\
\text { age in 2016 }\end{array}$ & $\begin{array}{c}\text { Distance } \\
\text { from glacier terminus in } \\
\text { 2016 }\end{array}$ & Altitude \\
\cline { 2 - 3 } & $\mathbf{( y r )}$ & $\mathbf{( m )}$ & \\
\hline 1 & $\sim 5$ & & $\sim 35$ & \\
\hline 2 & $\sim 10$ & $\sim 90$ & 3,025 \\
3 & $\sim 40$ & $\sim 180$ & 3,015 \\
4 & $\sim 65$ & $\sim 350$ & 3,000 \\
5 & $\sim 140$ & $\sim 800$ & 2,970 \\
6 & $\sim 170$ & $\sim 1,000$ & 2,885 \\
& & & 2,850
\end{tabular}

was then identified, encompassing a temporal range of 170 years and a spatial distance of 1,000 $\mathrm{m}$ (Figure 1), with the lowest limit at 2,850 $\mathrm{m}$ a.s.l. (Table 1), ca. $500 \mathrm{~m}$ above potential treeline (according to Pecher et al., 2011). Half of the stages were located within $200 \mathrm{~m}$ from the 2016 glacial terminus in order to deeply examine the early phases of the primary succession, i.e., the ones occurred in the last 40 years.

\section{Vegetation Surveys}

Three permanent quadrat plots $(5 \times 5 \mathrm{~m})$ were placed at each chronosequence stage, avoiding areas visibly disturbed by water erosion or deposition processes. Plant species composition was then described following the vertical point-quadrat method (Daget and Poissonet, 1971) at every node of a $25 \times 25 \mathrm{~cm}$ 
grid (accounting for a total of 441 sampling points). At each point, all vascular plants were identified at species or subspecies level, while cryptogams were pooled in an aggregated group. A complete list of all occasional species occurring within the plot but not found at the nodes was recorded as well, following the same approach as the phytosociological one (Braun-Blanquet, 1932). The species cover was calculated as its frequency of occurrence across the plot divided by the total number of sampling points. A percentage cover of $0.1 \%$ was attributed to all occasional species not found at the nodes but within the plot (Tasser and Tappeiner, 2005). Taxonomic nomenclature followed the new checklist of the Italian vascular flora (Bartolucci et al., 2018). Plant diversity of vascular plants was assessed for each plot in terms of species richness and ShannonWiener index (Magurran, 1988). Moreover, we associated a phytosociological optimum (at class level) to each vascular plant species according to Aeschimann et al. (2004) in order to identify different functional pools of species, which are characterized by similar ecological needs. We identified two functional species pools, corresponding to different vegetation successional stages: 1) pioneer species (belonging to Thlaspietea rotundifolii class) and 2) alpine grassland species (belonging to Caricetea curvulae, Carici rupestris-kobresietea, Elyno-seslerietea, Molinio-arrhenatheretea, Nardetea strictae, and Salicetea herbaceae classes). Following this approach, adopted in many different alpine contexts (e.g., Pittarello et al., 2016; Moris et al., 2017; Perotti et al., 2018), we computed species number and cover for each functional species pool in the different plots.

Additionally, we studied the population structure of two target species, Saxifraga and Silene, chosen according to the criteria of abundance and ubiquity along the chronosequence. Saxifraga was selected as the pioneer species, with a phytosociological optimum corresponding to Thlaspietea rotundifolii (Aeschimann et al., 2004). Silene was chosen as an alpine grassland species, with a phytosociological optimum corresponding to Caricetea curvulae (Aeschimann et al., 2004). For both target species, we determined the diameter (mean value of the 2 min and max perpendicular diameters, in $\mathrm{cm}$ ) of all individuals found in each vegetation plot, as a proxy of individual age (Benedict, 1989). We then assessed the population structure by calculating the frequencies of occurrence (number of individuals in $100 \mathrm{~m}^{2}$ ) of each $1 \mathrm{~cm}$ diameter class.

\section{Soil and Plant Tissue Analyses}

A soil profile close to each vegetation plot was opened and described following the FAO guidelines (FAO, 2006). Soil samples were then collected from each genetic horizon, airdried and sieved at $2 \mathrm{~mm}$. Soil $\mathrm{pH}$ was measured potentiometrically in deionized water (soil:water $=1: 2.5$ ). Total carbon (TC) and nitrogen (TN) were determined by dry combustion with an elemental analyzer (NA2100, CE Instruments, Rodano, Italia). Carbonate content was assessed by volumetric analysis. The content of total organic carbon (TOC) was determined by difference between TC and carbonate-C.

Amorphous iron oxides $\left(\mathrm{Fe}_{\mathrm{o}}\right)$ were extracted with an ammonium oxalate solution, buffered at pH 3 (Schwertmann,
1964), while total pedogenic iron oxides $\left(\mathrm{Fe}_{\mathrm{d}}\right)$ were determined by the dithionite-citrate-bicarbonate extraction (Mehra and Jackson, 2013). Two forms of phosphorus were assessed: total phosphorus (TP), determined following Bowman (1988), and bicarbonate extractable phosphorus $\left(\mathrm{P}_{\mathrm{av}}\right)$, assumed as readily available phosphate for plants (Olsen, 1954). The ammonium acetate extraction method ( $\mathrm{pH} 7$ ) was adopted to determine cation exchange capacity (CEC) (Chapman, 1965); basic cations (Ca, $\mathrm{Mg}, \mathrm{K})$ were then measured by Atomic Absorption Spectrophotometry (AAS, Perkin Elmer, Analyst 400, Waltham, MA, United States).

To evaluate the influence of vegetation on soil properties, in each plot three replicates of Saxifraga and Silene individuals with the largest diameters were sampled, as well as the underlying soil at $0-10 \mathrm{~cm}$ depth. For comparative purposes, three soil replicates without vegetation, close to the eradicated plants, were also collected at each stage.

The eradicated individuals of Saxifraga and Silene were placed in sealed polyethylene bags, immediately stored at $4^{\circ} \mathrm{C}$ in a portable refrigerator, and transported to the laboratory, where green stems and leaves were separated. Aboveground green tissues (i.e., stems and leaves) were dried, grounded to $0.5 \mathrm{~mm}$ and analyzed to assess total $\mathrm{C}, \mathrm{N}$, and $\mathrm{P}$ contents following the above-mentioned procedures.

Soil samples were separated in two aliquots: one was air-dried, sieved, and analyzed to determine TOC, TN, TP, and $\mathrm{P}_{\mathrm{av}}$ as described above. The other aliquot was processed within $24 \mathrm{~h}$ from sample collection, in order to measure microbial biomass $\mathrm{C}$ $\left(\mathrm{C}_{\text {micr }}\right)$ and $\mathrm{N}\left(\mathrm{N}_{\text {micr }}\right)$. In particular, a $30 \mathrm{~g}$ aliquot was extracted with $100 \mathrm{ml} \mathrm{K}_{2} \mathrm{SO}_{4} 0.5 \mathrm{M}$, while a $10 \mathrm{~g}$ aliquot was fumigated with chloroform for $18 \mathrm{~h}$ before extraction with $50 \mathrm{ml} \mathrm{K}_{2} \mathrm{SO}_{4} 0.5 \mathrm{M}$. The DOC concentration in non-fumigated soil extracts was determined with a TOC analyser (Elementar, Vario TOC, Hanau, Germany) after filtration with $0.45 \mu \mathrm{m}$ membrane filters). The same procedure was applied to fumigated samples; the difference in DOC between fumigated and non-fumigated samples, corrected by a recovery factor of 0.45 , was $\mathrm{C}_{\text {micr }}$ (Brookes et al., 1985).

In order to measure $\mathrm{N}_{\text {micr }}$, ammonium (extractable $\mathrm{N}-\mathrm{NH} 4^{+}$) concentrations in soil extracts were determined spectrophotometrically (U-2000, Hitachi, Tokyo, Japan) by the method described by Crooke and Simpson (1971). Nitrate (extractable $\mathrm{N}_{-} \mathrm{NO}_{3}{ }^{-}$) was determined following Cucu et al. (2014). Total dissolved nitrogen (extractable TDN) in the extracts was determined as reported for DOC. Dissolved organic nitrogen (extractable DON) was determined as the difference between extractable TDN and inorganic nitrogen (extractable $\left.\mathrm{N}-\mathrm{NH}_{4}{ }^{+}+\mathrm{N}-\mathrm{NO}_{3}{ }^{-}\right)$. Microbial nitrogen $\left(\mathrm{N}_{\text {micr }}\right)$ was then calculated as the difference in extractable TDN between fumigated and non-fumigated samples, corrected by a recovery factor of 0.54 (Brookes et al., 1985). All analyses were carried out in triplicate.

\section{Statistical Analyses}

The differences among the six stages of the chronosequence in terms of the considered vegetation variables (i.e., cryptogam and vascular plant cover, the two plant diversity indices, and species 

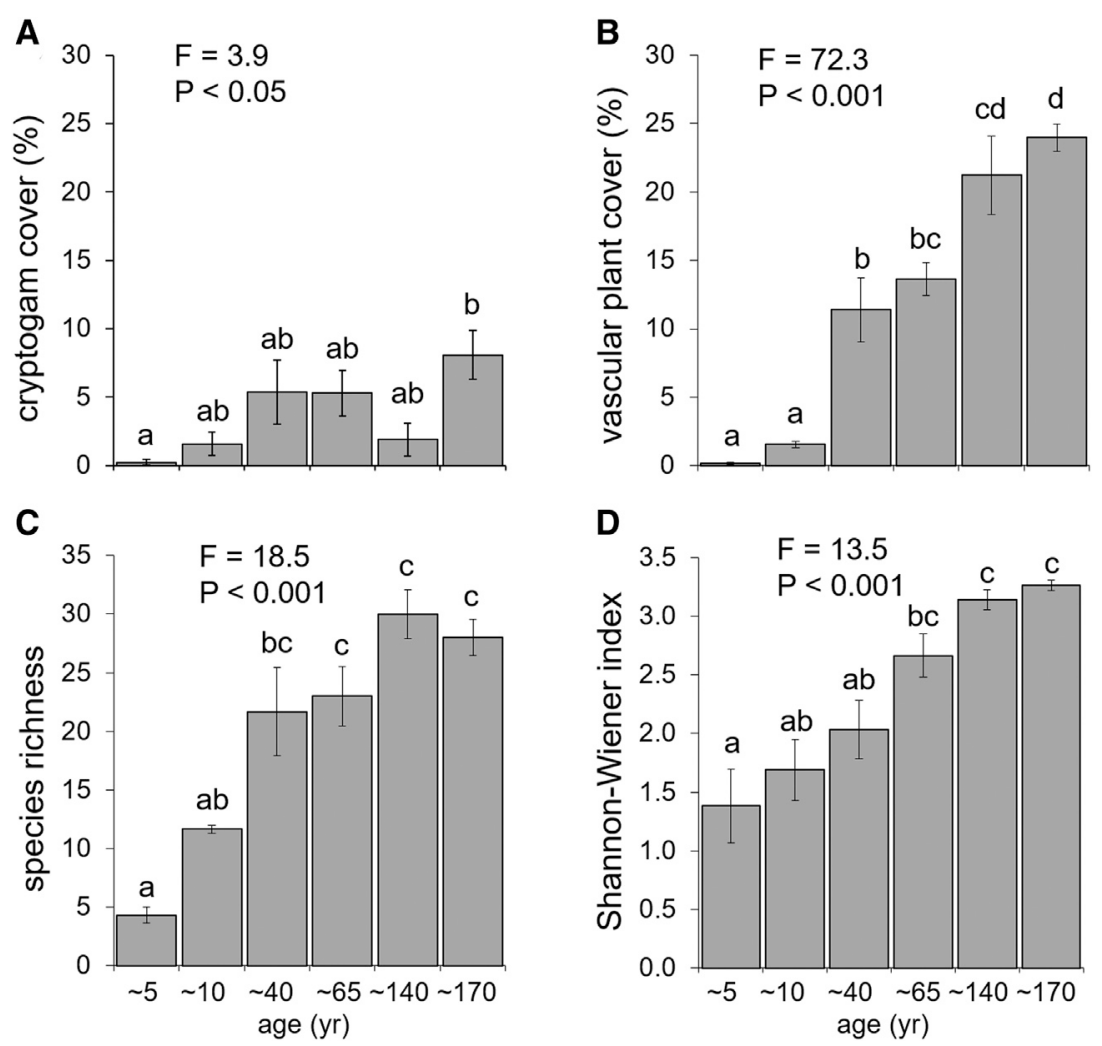

FIGURE 2 | Plant species cover ((A), cryptogams; (B), vascular plants) and diversity indexes ((C), species richness; (D), Shannon-Wiener index) along the six stages of the chronosequence. Different letters indicate significant differences $(p<0.05)$ among stages according to Tukey's HSD test.

number and cover for the two functional species pools) were tested performing a one-way ANOVA. To investigate the variations within the population structures of Saxifraga and Silene along the chronosequence we performed a PERMANOVA for each species on the frequencies of diameter classes among stages. The similarity index was calculated using Euclidean distance method and 9,999 permutations were set.

The soil property changes triggered by Saxifraga and Silene were analyzed with two separate one-way ANOVAs. The same analysis was carried out on chemical properties (i.e., TOC, TN, TP, C:N, and N:P) of Saxifraga and Silene tissues, among stages and between the two plant species.

For univariate tests, assumptions of normality and homoscedasticity were checked with Shapiro-Wilk's and Levene's tests, respectively and, in case of assumption violation, logarithmic and square-root transformations were applied to variables prior to perform the ANOVAs. Whenever normal distribution or homoscedasticity did not occur, even after transformations, we performed the non-parametric KruskalWallis test. Tukey's and Dunn's post-hoc tests were adopted for one-way ANOVA and Kruskal-Wallis, respectively, in case of significant differences.

In order to describe the interactions between soil properties and vegetation cover along the chronosequence, two matrices were arranged: 1) a soil property matrix, with TOC, TN, TP, $\mathrm{P}_{\mathrm{av}}$, $\mathrm{C}_{\text {micr }}$, and $\mathrm{N}_{\text {micr }}$ of soil samples without vegetation, and 2) a vegetation matrix, including the covers of cryptogams, total vascular plants, pioneer species, and alpine grassland species. A Mantel test was used to calculate the correlation between the soil and vegetation matrices. A preliminary detrended crosscorrelation analysis (DCCA) was performed to assess the lengths of gradients (Ter Braak and Smilauer, 1998). The DCCA revealed the presence of short (linear) gradients $(<4$ standard deviations) so we performed a redundancy analysis (RDA) between the two matrices (Ter Braak and Smilauer, 1998).

Univariate analyses were carried out with SPSS 24 (SPSS, 2016), while PERMANOVA and Mantel test analysis with PAST 3.15 (Hammer et al., 2001) and RDA with CANOCO 4.5 (Ithaca, NY, United States); significance was set at $p<0.05$.

\section{RESULTS}

\section{Vegetation}

A total of 65 vascular plants, belonging to 19 botanical families, were recorded within the 18 plots. The most abundant species were Saxifraga bryoides L., Cerastium uniflorum Clairv., Silene acaulis subsp. bryoides, Poa alpina L., and Saxifraga oppositifolia subsp. glandulifera. No species belonging to the Fabaceae family were found in the study area. Five years since deglaciation, seven species colonized the siliceous parent material of the Lauson foreland and the pioneer Saxifraga oppositifolia was the most 


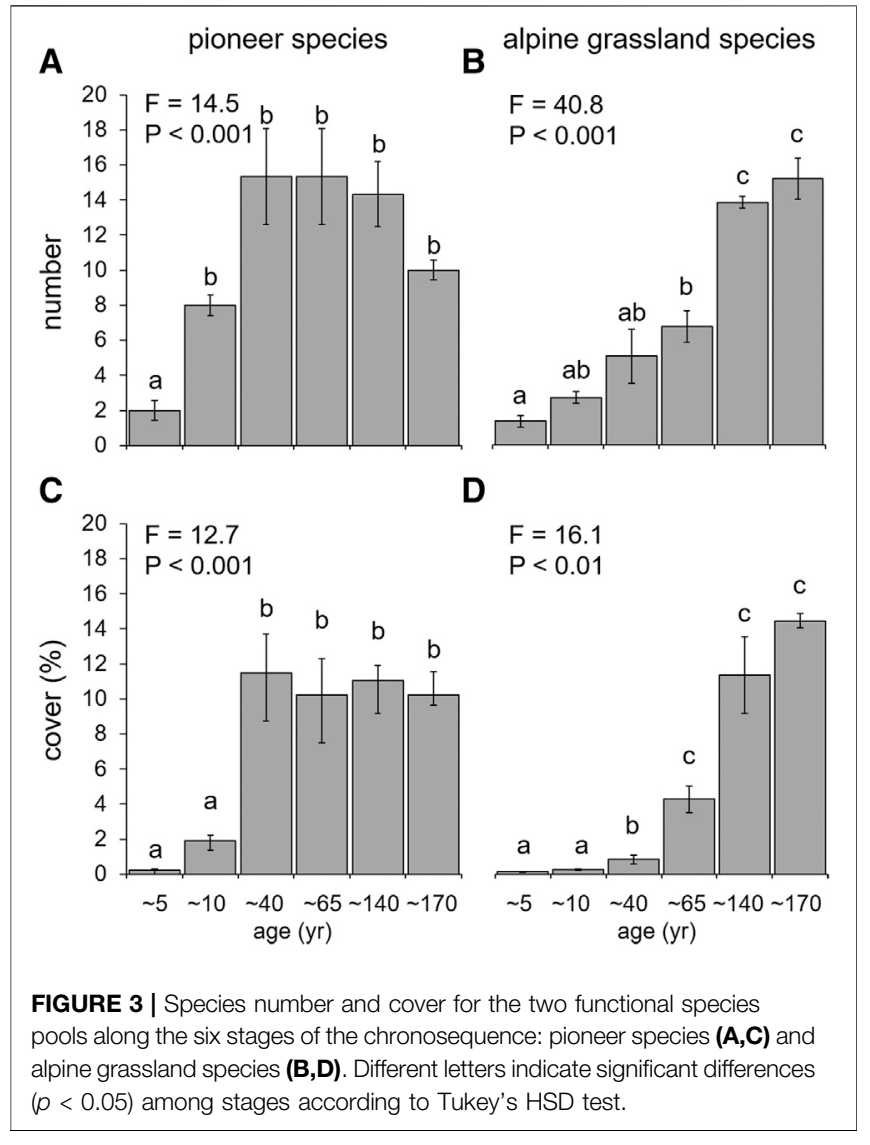

widespread in terms of both frequency and cover. Vegetation cover increased significantly along the chronosequence, for both cryptogams and vascular plants (Figures 2A,B). In particular, vascular plant cover increased from values close to 0 at $5-10$ years since deglaciation to $24 \%$ at the 170 years stage (Figure $2 \mathbf{b}$ ). Species richness and Shannon-Wiener index increased along the chronosequence as well (Figures 2C,D).

The number of species belonging to both functional species pools increased along the chronosequence as well (Figures 3A,B). In particular, pioneer species number significantly increased already after 10 years and, even if not statistically significant, tended to decline at older stages, while alpine grassland species number showed a slower but progressive increase along the whole chronosequence. Species cover significantly differed among stages for both pioneer and alpine grassland species, reaching the highest values since 40 and 65 years after deglaciation, respectively (Figures $\mathbf{3 C}, \mathbf{D}$ ).

Overall, we studied 1931 plant individuals for the population structure analysis, 775 were Saxifraga (observed in 14 plots out of 18) and 1,176 Silene (observed in 12 plots out of 18).

In the 5 years deglaciated plots, many Saxifraga individuals (ca. 70 in $100 \mathrm{~m}^{2}$ ) were counted, with the highest frequencies in the $1 \mathrm{~cm}$ diameter class (Figure 4A). The highest number of individuals and cover was found in plots deglaciated for 40 years, with plants occurring in all diameter classes up to $25 \mathrm{~cm}$ and abundance of large individuals (mean diameter $13 \mathrm{~cm}$ and several individuals with diameter over $30 \mathrm{~cm}$ ). This species almost disappeared in plots deglaciated for longer times. Conversely, no individuals of Silene were found within the first deglaciation stage, while it sparsely colonized young moraines only after 10 years (Figure 4B). The species became more frequent after 40 years (mainly with small individuals) and spread on the 65 years-old areas, with diameter classes up to $19 \mathrm{~cm}$ constantly present. In the last two stages, the frequencies of regenerating individuals ( 1 and $2 \mathrm{~cm}$ classes) doubled and large individuals $(45 \mathrm{~cm}$ class) were detected.

According to PERMANOVA results, the distribution frequency of individual diameters differed among the chronosequence stages for both target species (Figure 4).

\section{Soil Development}

According to the WRB classification (IUSS Working Group WRB, 2015), the soils of the first and third stages of the chronosequence were classified as Eutric Skeletic Regosols, while the others as Eutric Skeletic Regosols (Turbic). Soil chemical properties are shown in Table 2 . We observed two to five genetic horizons in the soil pits of each stage, including A, $\mathrm{AC}, \mathrm{CA}$, and $\mathrm{C}$ horizons, with soil depths $(\mathrm{A}+\mathrm{AC}$ or $\mathrm{CA}$ horizons) ranging from 15 to over $40 \mathrm{~cm}$. Soil $\mathrm{pH}$ values ranged from 8.9 (C horizon deglaciated for 10 years) to around 6.0 in the upper horizon of the 170 years old stage. $\mathrm{pH}$ values decreased below 7.0 only in the surface horizons of the 65 years-old stage. Despite the high $\mathrm{pH}$ values, no carbonates were detected. Total organic carbon (TOC) was always greater in surface than in deep soil horizons and increased along the chronosequence, with a maximum content of $26.2 \mathrm{~g} \cdot \mathrm{kg}^{-1}$ in the A1 horizon deglaciated for 170 years. Organic horizons were never detected. Total nitrogen (TN) was below the limit of quantification in soils up to 40 years since deglaciation and in all C horizons of the chronosequence (except the 140 years-old one), while the greatest contents were detected in A horizons, ranging between 0.2 and $1.5 \mathrm{~g} \cdot \mathrm{kg}^{-1}$. As a consequence, the TOC: TN ratio varied between 8 (at 40 years) and 17 (at 170 years).

Younger soils (i.e., up to 40 years) showed higher $\mathrm{Fe}_{\mathrm{o}}$ concentrations than older ones and both $\mathrm{Fe}_{\mathrm{o}}$ and $\mathrm{Fe}_{\mathrm{d}}$ were higher in surface horizons than in deeper ones. The $\mathrm{Fe}_{\mathrm{o}}: \mathrm{Fe}_{\mathrm{d}}$ ratio, which indicates the ratio between poorly crystalline $\mathrm{Fe}$ (hydr)oxides and pedogenetic Fe (hydr)oxides, decreased along the chronosequence with the lowest value in the soils deglaciated for 170 years, in $\mathrm{A} 2$ and $\mathrm{AC}$ horizons $\left(0.4 \mathrm{~g} \cdot \mathrm{kg}^{-1}\right)$. Total phosphorus (TP) ranged between 593 and $776 \mathrm{mg} \cdot \mathrm{kg}^{-1}$ without recognizable age or depth trends, whereas the available form $\left(\mathrm{P}_{\mathrm{av}}\right)$ was $0.5 \mathrm{mg} \cdot \mathrm{kg}^{-1}$ in the youngest soil stages and reached $4 \mathrm{mg} \cdot \mathrm{kg}^{-1}$ in the $\mathrm{A}$ horizons of the 170 years-old stage. Cation-exchange capacity (CEC) ranged between $0.89 \mathrm{cmol}_{(+)} \cdot \mathrm{kg}^{-1}$ in the $\mathrm{C}$ horizon of the 65 years-old stage and $10.1 \mathrm{cmol}_{(+)} \cdot \mathrm{kg}^{-1}$ in the oldest topsoil (Table 3). Base saturation (SATB) was greater in younger stages, ranging between $67 \%$ and $100 \%$ in the first 40 years-old stages. In the oldest stages, it was generally lower (except for A horizon from the 65 years-old stage with $83 \%$ ) with a minimum value of $23.7 \%$ in the AC horizon of the 140 years ice-free stage. Calcium ion was the main element saturating the exchange complex, both in terms of 


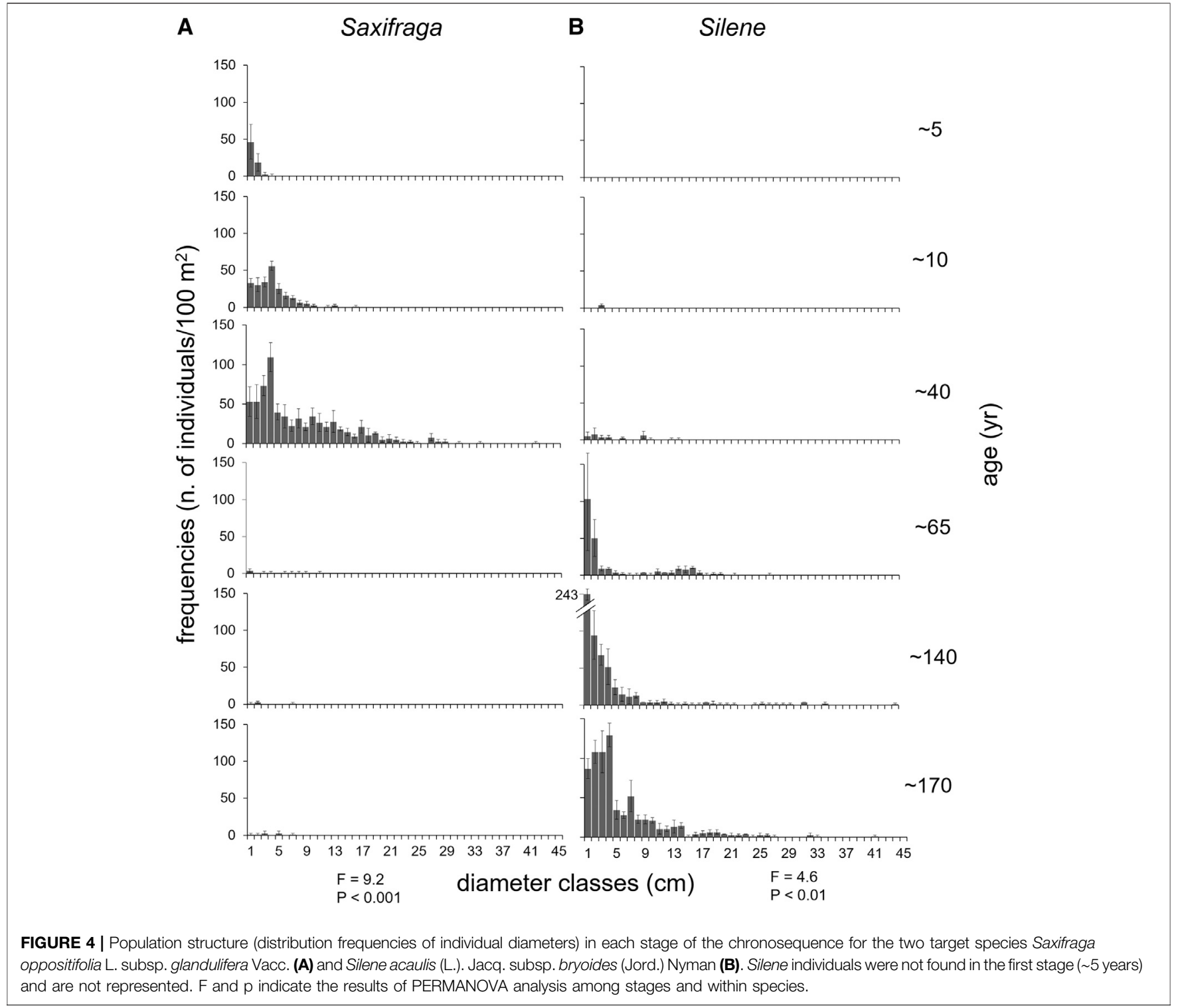

concentration and ratio, especially in deeper soil horizons (Table 3).

\section{Soil and Plant Interaction}

Chemical composition in the topsoil layers sampled under Saxifraga (SaxS), Silene (SilS) and in the corresponding nonvegetated soils (BareS) significantly differed within the same age and among stages (Figure 5). The comparisons among all the three target soils were possible only at the third and fourth stages, where we found individuals of both Saxifraga and Silene with adequate development. Total OC showed a lag time in the first stages and then increased, especially with Silene establishment, reaching 6-8 g.C. $\mathrm{kg}^{-1}$ after 140 years, whereas the $\mathrm{C}$ content in the non-vegetated soil reached no more than $4 \mathrm{~g} \cdot \mathrm{C} \cdot \mathrm{kg}^{-1}$ (Figure 5A). Total $\mathrm{N}$ followed the same trend with more pronounced differences between the vegetated and non- vegetated soil samples (Figure 5B). At the 170 years-old stage SilS showed the highest $\mathrm{N}$ content. The stoichiometric TOC:TN ratio did not differ among target soils nor among stages, except for a higher value of SilS compared to BareS at the fifth stage (Figure 5C). Microbial $\mathrm{C}$ and $\mathrm{N}$ in vegetated and non-vegetated soils was comparable in the youngest stages and then significantly increased along the chronosequence in SaxS and SilS (Figures 5D,E). Total phosphorus content did not show significant trends in the three series of soils, while an increasing nutrient availability along the chronosequence, due to the presence of the two species, was observed (Figures 5F,G). Lower $\mathrm{P}_{\mathrm{av}}$ concentrations were found in BareS if compared to SaxS at 10 years since deglaciation and to SilS at 140 and 170 years since deglaciation, respectively.

In plant tissues, a decreasing trend occurred in $\mathrm{P}$ and $\mathrm{N}$ with time for Saxifraga and Silene, respectively, leading to a 
TABLE 2 | Chemical properties of soil pits along the six stages of the chronosequence. pH; TOC, total organic carbon; TN, total nitrogen; Fe $\mathrm{d}_{\mathrm{d}}$, pedogenic iron oxides; Fe, iron amorphous oxides; $\mathrm{Fe}_{\mathrm{o}}: \mathrm{Fe}_{\mathrm{d}}$, poorly crystalline to pedogenic iron oxide ratio; TP, total phosphorus; $\mathrm{P}_{\text {av, }}$, bicarbonate extractable (available) phosphorus.

\begin{tabular}{|c|c|c|c|c|c|c|c|c|c|c|c|}
\hline \multirow{2}{*}{$\frac{\text { Age }}{\mathrm{Yr}}$} & \multirow[t]{2}{*}{ Horizon } & \multirow{2}{*}{$\begin{array}{c}\text { Depth } \\
\text { Cm }\end{array}$} & \multirow[t]{2}{*}{$\mathrm{pH}$} & \multirow{2}{*}{$\frac{\mathrm{TOC}}{\mathrm{g} \cdot \mathrm{kg}^{-1}}$} & \multirow{2}{*}{$\frac{\mathrm{TN}}{\mathrm{g} \cdot \mathrm{kg}^{-1}}$} & \multirow[t]{2}{*}{ TOC:TN } & \multirow{2}{*}{$\frac{\mathrm{Fe}_{\mathrm{o}}}{\mathrm{g} \cdot \mathrm{kg}^{-1}}$} & \multirow{2}{*}{$\frac{\mathrm{Fe}_{\mathrm{d}}}{\mathrm{g} \cdot \mathrm{kg}^{-1}}$} & \multirow[t]{2}{*}{$F e_{o}: F e_{d}$} & \multirow{2}{*}{$\frac{\mathrm{TP}}{\mathrm{mg} \cdot \mathrm{kg}^{-1}}$} & \multirow{2}{*}{$\frac{\mathrm{P}_{\mathrm{av}}}{\mathrm{mg} \cdot \mathrm{kg}^{-1}}$} \\
\hline & & & & & & & & & & & \\
\hline \multirow[t]{2}{*}{.5} & CA & $0-5 / 10$ & 8.5 & 0.3 & 0 & - & 1.6 & 1.9 & 0.8 & 592.9 & 0.8 \\
\hline & C & 5/10-35+ & 8.3 & 0 & 0 & - & 1.9 & 2.0 & 1.0 & 671.4 & 0.5 \\
\hline \multirow[t]{2}{*}{$\sim 0$} & CA & $0-3$ & 7.7 & 0.3 & 0 & - & 0.8 & 1.6 & 0.5 & 643.2 & 0.7 \\
\hline & C & $3-15+$ & 8.9 & 0.2 & 0 & - & 1.3 & 1.7 & 0.8 & 700.0 & 0.5 \\
\hline \multirow[t]{3}{*}{40} & A & $0-3$ & 7.1 & 1.6 & 0.2 & 8.0 & 1.4 & 2.8 & 0.5 & 727.8 & 1.1 \\
\hline & CA & 3-14 & 7.4 & 0.2 & 0 & - & 1.7 & 2.3 & 0.7 & 775.6 & 0.9 \\
\hline & C & $14-20+$ & 7.3 & 0 & 0 & - & 1.8 & 2.3 & 0.8 & 705.6 & 0.7 \\
\hline \multirow[t]{3}{*}{.65} & $A$ & $0-4$ & 6.2 & 8.1 & 0.6 & 13.5 & 1.2 & 2.7 & 0.4 & 713.5 & 3.5 \\
\hline & CA & $4-15$ & 6.9 & 0.1 & 0 & - & 1.0 & 1.8 & 0.5 & 699.6 & 1.4 \\
\hline & C & $15-22+$ & 6.9 & 0.1 & 0 & - & 0.5 & 1.1 & 0.5 & 691.9 & 0.7 \\
\hline \multirow[t]{3}{*}{$\sim 40$} & $A$ & $0-5 / 8$ & 6.2 & 14.1 & 0.9 & 15.7 & 1.1 & 2.7 & 0.4 & 688.4 & 3.4 \\
\hline & $\mathrm{AC}$ & 5/8-18/20 & 6.8 & 0.7 & 0.1 & - & 0.9 & 1.9 & 0.5 & 751.2 & 0.9 \\
\hline & C & $18 / 20-40+$ & 7.4 & 0 & 0 & - & 0.9 & 1.6 & 0.5 & 605.9 & 0.7 \\
\hline \multirow[t]{5}{*}{-170 } & A1 & $0-3$ & 6.0 & 26.2 & 1.5 & 17.5 & 1.0 & 2.5 & 0.4 & 724.4 & 4.0 \\
\hline & $\mathrm{A} 2$ & $3-10$ & 6.0 & 11.3 & 0.8 & 14.1 & 0.8 & 2.0 & 0.4 & 728.6 & 2.8 \\
\hline & $A C$ & $10-15$ & 6.4 & 0.5 & 0 & - & 0.7 & 1.7 & 0.4 & 683.4 & 0.8 \\
\hline & $\mathrm{AC} / \mathrm{C}$ & $15-25 / 30$ & 7.1 & 0 & 0 & - & 0.7 & 1.7 & 0.4 & 648.7 & 0.7 \\
\hline & C & $25 / 30-40+$ & 7.4 & 0.5 & 0 & - & 0.7 & 1.7 & 0.4 & 609.9 & 0.6 \\
\hline
\end{tabular}

TABLE 3 | Cation-exchange capacity and base saturation of soil pits along the six stages of the chronosequence. CEC, cation-exchange capacity; Mgex, magnesium exchangeable cations; $\mathrm{Ca}_{\mathrm{ex}}$, calcium exchangeable cations; $\mathrm{K}_{\mathrm{ex}}$, potassium exchangeable cations; SATB, base saturation; satMg, magnesium saturation; satCa, calcium saturation; satK, potassium saturation, Ca:Mg, calcium to magnesium ratio; Mg: $\mathrm{K}$, magnesium to potassium ratio.

\begin{tabular}{|c|c|c|c|c|c|c|c|c|c|c|c|}
\hline$\frac{\text { Age }}{\mathrm{Yr}}$ & Horizon & $\frac{\text { CEC }}{\mathrm{cmol}_{(+)} \cdot \mathrm{kg}^{-1}}$ & $\frac{\mathrm{Mg}_{\mathrm{ex}}}{\mathrm{cmol}_{(+)} \cdot \mathrm{kg}^{-1}}$ & $\frac{\mathrm{Ca}_{\mathrm{ex}}}{\mathrm{cmol}_{(+)} \cdot \mathrm{kg}^{-1}}$ & $\frac{\mathrm{K}_{\mathrm{ex}}}{\mathrm{cmol}_{(+)} \cdot \mathbf{k g}^{-1}}$ & $\frac{\text { SATB }}{\%}$ & $\frac{\text { Sat } \mathbf{M g}}{\mathbf{g} \cdot \mathbf{k g}^{-1}}$ & $\frac{\text { Sat Ca }}{\mathrm{g} \cdot \mathbf{k g}^{-1}}$ & $\frac{\text { Sat K }}{\mathbf{g} \cdot \mathbf{k g}^{-1}}$ & Ca:Mg & Mg:K \\
\hline \multirow[t]{2}{*}{.5} & $\mathrm{CA}$ & - & - & - & - & - & - & - & - & - & - \\
\hline & C & 2.00 & 0.11 & 1.23 & 0.20 & 77.00 & 5.50 & 61.50 & 10.00 & 11.18 & 0.55 \\
\hline \multirow[t]{2}{*}{ 10 } & $\mathrm{CA}$ & 1.29 & 0.05 & 0.89 & 0.04 & 75.61 & 3.54 & 69.05 & 3.02 & 19.51 & 1.17 \\
\hline & $C$ & 1.53 & 0.07 & 3.93 & 0.10 & 100.00 & 4.58 & 87.14 & 6.54 & 56.14 & 0.70 \\
\hline \multirow[t]{3}{*}{40} & $A$ & - & - & - & - & - & - & - & - & - & - \\
\hline & $\mathrm{CA}$ & 1.18 & 0.07 & 0.73 & 0.05 & 72.33 & 5.96 & 62.12 & 4.25 & 10.43 & 1.40 \\
\hline & $\mathrm{C}$ & 1.67 & 0.09 & 0.92 & 0.10 & 66.69 & 5.51 & 54.98 & 6.20 & 9.98 & 0.89 \\
\hline \multirow[t]{3}{*}{-65} & $A$ & 2.67 & 0.18 & 1.94 & 0.11 & 83.36 & 6.79 & 72.51 & 4.07 & 10.69 & 1.67 \\
\hline & CA & 2.05 & 0.07 & 0.76 & 0.10 & 45.52 & 3.27 & 37.15 & 5.09 & 11.34 & 0.64 \\
\hline & C & 0.89 & 0.04 & 0.44 & 0.05 & 59.31 & 4.34 & 49.47 & 5.50 & 11.41 & 0.79 \\
\hline \multirow[t]{3}{*}{-140 } & A & 7.36 & 0.26 & 2.36 & 0.12 & 37.23 & 3.49 & 32.04 & 1.69 & 9.18 & 2.06 \\
\hline & $A C$ & 4.11 & 0.09 & 0.84 & 0.04 & 23.67 & 2.28 & 20.42 & 0.97 & 8.96 & 2.34 \\
\hline & C & 1.36 & 0.07 & 0.66 & 0.09 & 60.29 & 5.15 & 48.53 & 6.62 & 9.43 & 0.78 \\
\hline \multirow[t]{5}{*}{ 〜70 } & A1 & 10.08 & 0.34 & 2.16 & 0.18 & 29.40 & 2.78 & 25.21 & 1.41 & 6.31 & 1.88 \\
\hline & $\mathrm{A} 2$ & 7.13 & 0.19 & 1.26 & 0.10 & 24.31 & 1.63 & 21.81 & 0.87 & 6.63 & 1.88 \\
\hline & $A C$ & 0.99 & 0.06 & 0.53 & 0.06 & 65.54 & 6.17 & 53.78 & 5.60 & 8.72 & 1.10 \\
\hline & $\mathrm{AC} / \mathrm{C}$ & 0.96 & 0.05 & 0.54 & 0.06 & 68.00 & 4.98 & 56.60 & 6.41 & 11.36 & 0.78 \\
\hline & C & 1.08 & 0.04 & 0.59 & 0.06 & 64.50 & 4.13 & 55.25 & 5.13 & 13.39 & 0.80 \\
\hline
\end{tabular}

corresponding significant N:P and C:N increase (Figure 6). No differences were found between the two target species for any of the considered chemical features at the third and fourth stages, i.e., where both species were found.

A significant correlation was detected between the soil and vegetation matrices by Mantel test $(\mathrm{r}=0.45, p<0.001)$, highlighting that chronosequence stages with similar soil properties had similar vegetation covers. Significant correlations between soil and vegetation variables were observed (Figure 7), explaining $74.2 \%$ of the distribution fitting with the first axis and $2.8 \%$ with the second axis.
Cryptogam cover appeared weakly associated with soil properties, as highlighted by the arrangement of the arrow relatively to the soil ones. Pioneer species cover showed an intermediate trend between cryptogam and vascular plant covers, this latter being strongly related to $\mathrm{TN}, \mathrm{C}_{\text {micr }}$, and $\mathrm{N}_{\text {micr. }}$. Alpine grassland species cover was, instead, strongly associated with TOC and $\mathrm{P}_{\mathrm{av}}$. The only variable arranged in the left part of the bi-plot was TP, showing a contrasting distribution compared to most of the other variables. The chronosequence stages separated well along the two axes of the bi-plot. More specifically, the first two stages were at the 


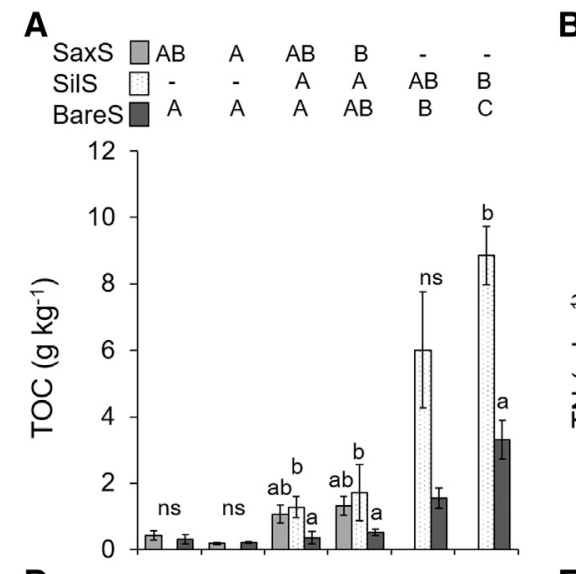

D

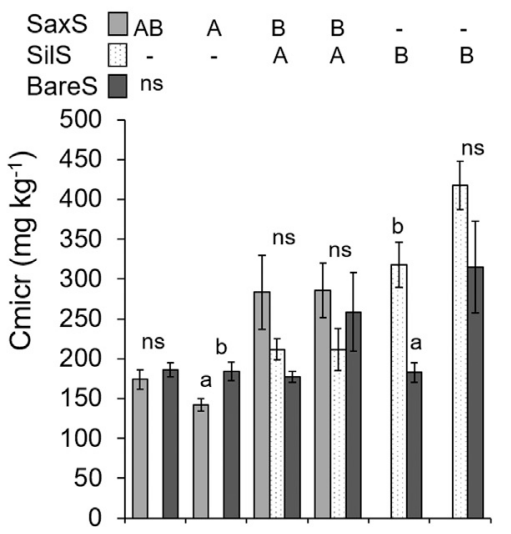

F

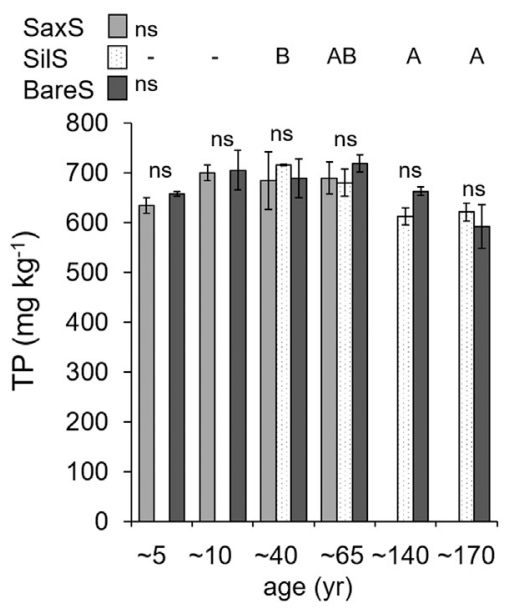

B

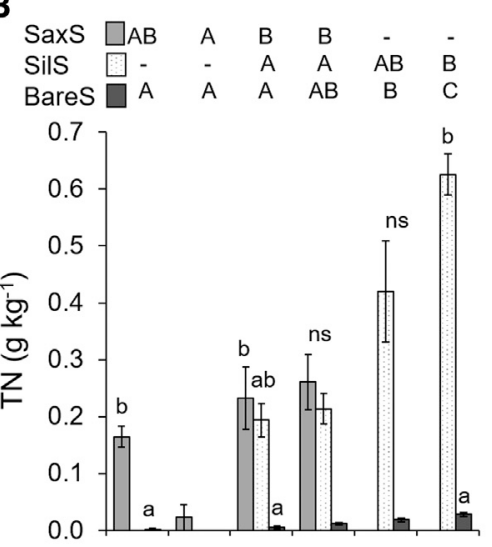

E

$\begin{array}{llllll}\text { SaxS } \square \text { A } & \text { A } & \text { B } & \text { B } & - & - \\ \text { SilS } \square- & - & \text { A } & \text { AB } & \text { B } & \text { C }\end{array}$ Bares $\square$ AB A AB BC BC C

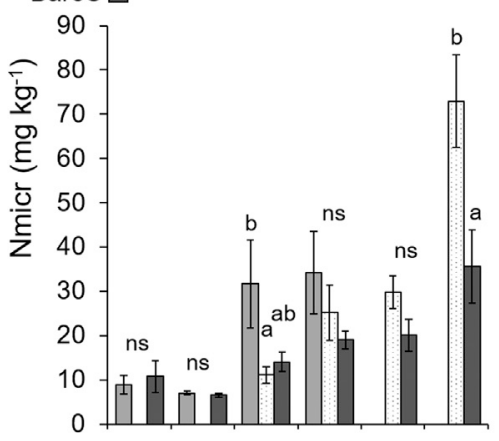

G
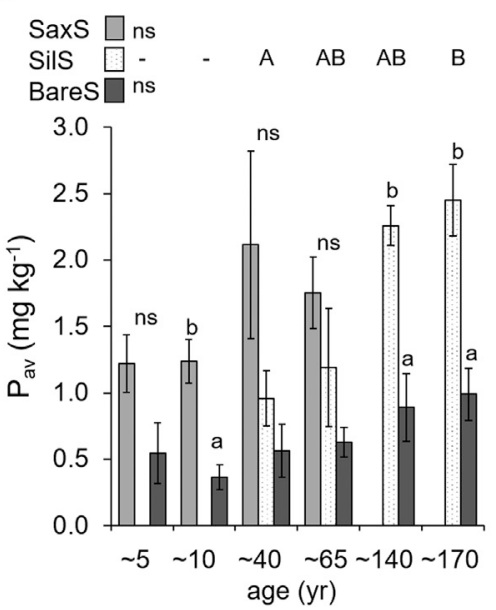

C

$$
\begin{aligned}
& \text { Saxs } \square \text { ns } \\
& \text { Sils } \square \text { ns } \\
& \text { Bares } \square \text { ns }
\end{aligned}
$$

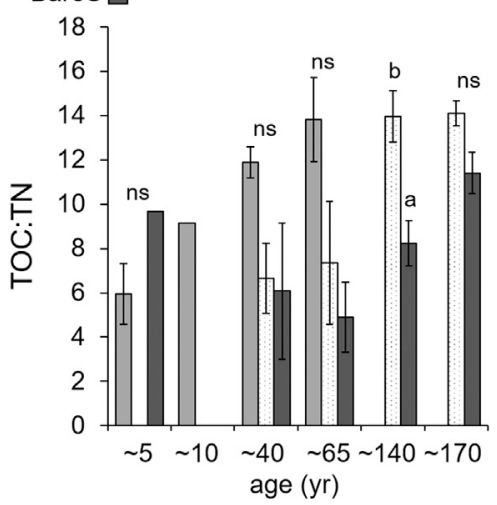

$\square$ Saxs
$\square$ Sils
$\square$ Bares

FIGURE 5 | Chemical properties of target soils along the six stages of the chronosequence. SaxS, soil under individuals of Saxifraga oppositifolia L. subsp. glandulifera Vacc.; SilS, soil under Silene acaulis (L.) Jacq subsp. bryoides (Jord.) Nyman; BareS, bare soil; TOC, total organic carbon (A); TN, total nitrogen (B); TOC:TN,

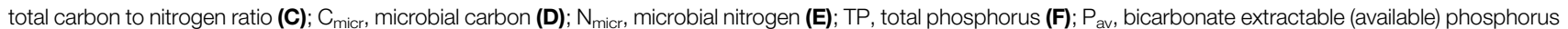
(G). Different letters indicate significant differences $(p<0.05)$ among stages within each target soil (uppercase letters) and among target soils within each stage (lowercase letters) according to Tukey's HSD test. ns, $p \geq 0.05$.

opposite of both soil and vegetation features, while the two intermediate stages were mostly related to the covers of cryptogam and pioneer species and the oldest ones related to more developed soils (in terms of TOC and $\mathrm{P}_{\mathrm{av}}$ ) and to latesuccessional species.

\section{DISCUSSION}

The univariate and multivariate analyses highlighted a clear pattern of progressive soil development and vegetation successional dynamics throughout the six stages of the Lauson 


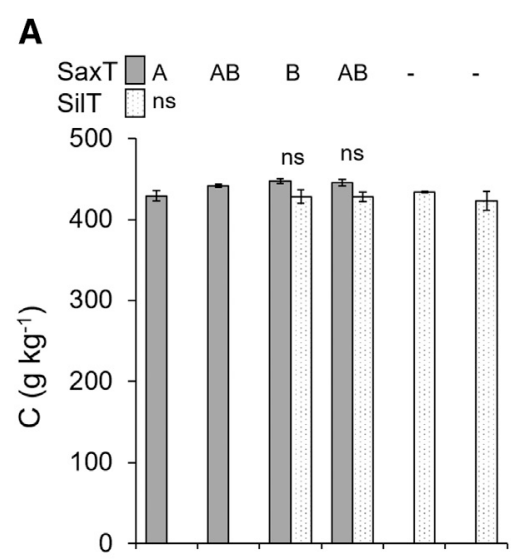

D

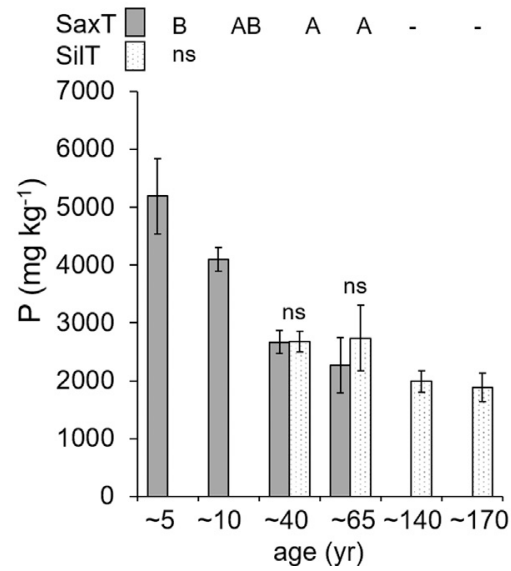

B

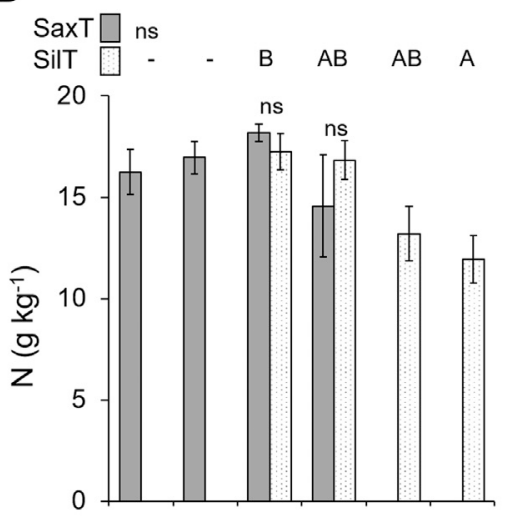

E

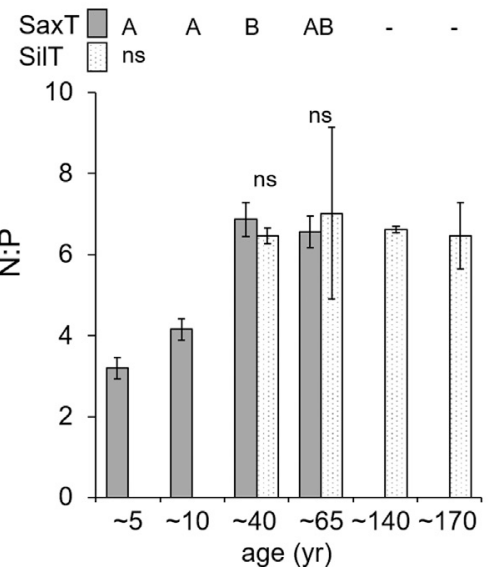

C SaxT $\square$ ns
SilT $\square$ - $\quad$ A $\quad$ AB $\quad$ AB $\quad$ B

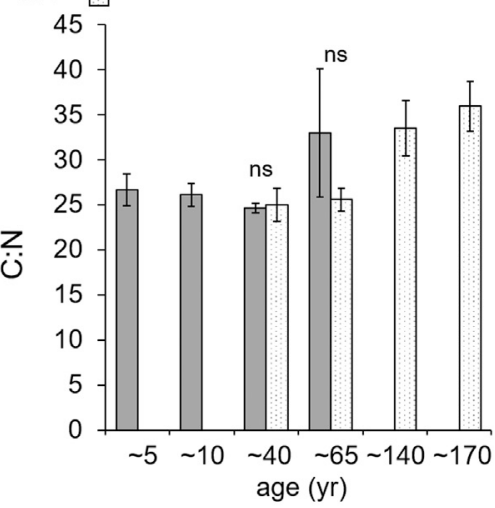

$\square$ SaxT

FIGURE 6 | Chemical properties of plant tissues for the target species along the six stages of the chronosequence. SaxT, Saxifraga oppositifolia L. subsp. glandulifera Vacc. L. tissues; SilT, Silene acaulis (L.) Jacq subsp. bryoides (Jord.) Nyman tissues; C, carbon (A); N, nitrogen (B); C:N, carbon to nitrogen ratio (C); P, phosphorus (D); N:P, nitrogen to phosphorus ratio (E). Different letters indicate significant differences $(p<0.05)$ among stages within each target species (uppercase letters) and between target species within each stage (lowercase letters) according to Tukey's HSD test. ns, $p \geq 0.05$.

proglacial foreland, at increasing ages from deglaciation. More specifically, the colonization patterns along the chronosequence of the foreland by vegetation, considering the large difference in elevation between the lower limit of the study area and the potential treeline $(500 \mathrm{~m})$, was extremely rapid in the first forty years following deglaciation, in terms of both species richness and cover. An average of four and twelve different species were able to colonize the Lauson proglacial till after 5 and 10 years since deglaciation, respectively. This early process was more rapid than the one observed in the Austrian Alps by Tscherko et al. (2005) and Raffl et al. (2006), in study areas located around the potential treeline (study areas at 2,300-2,450 $\mathrm{m}$ a.s.l., with a potential treeline at 2,400 $\mathrm{m}$ a.s.l. according to Pecher et al., 2011). Conversely, the studied area was comparable to the results obtained by Burga et al. (2010) in Switzerland, in a proglacial area located at 1900-2,100 $\mathrm{m}$ a.s.l., i.e., completely below the potential treeline, which is located at 2,450 $\mathrm{m}$ a.s.l. (Pecher et al., 2011). Similar results were also obtained by Cannone et al. (2008) in the Italian Alps, in a study area located at 2,700-2,850 $\mathrm{m}$ a.s.l., $300-450 \mathrm{~m}$ above the potential tree line, located at 2,400 $\mathrm{m}$ a.s.l. (Pecher et al.,
2011), and by Matthews and Vater (2015) in southern Norway (study area at 1,420 $\mathrm{m}$ a.s.l., $400 \mathrm{~m}$ above the local tree line). In all these environments, substrate stability, together with the ability of seeds to reach colonization sites, created a suitable environment for the establishment of pioneer species. The lack of seeds, stated by several studies as a fundamental limiting factor (Chapin et al., 1994; Jones and del Moral, 2009), probably was not the major constraint for plant colonization in the young Lauson foreland, likely because of the short distance between bare sites, freshly released by the glacier, and plant communities growing on nearby slopes, which acted as seed sources. We suggest that, under the studied conditions, other factors, such as drought, frost and cryoturbation may have played a major role limiting plant establishment, according to Erschbamer and Caccianiga (2016). These factors are naturally interrelated with proglacial micro-topography and with the occurrence of protected microsites, important also for nutrient accumulation. In the Lauson chronosequence, after 65 years since deglaciation, vegetation cover increased due to the additive contribution of the alpine grassland species that partially replaced pioneer ones, contributing to an overall rise in vascular plant cover. Despite the 


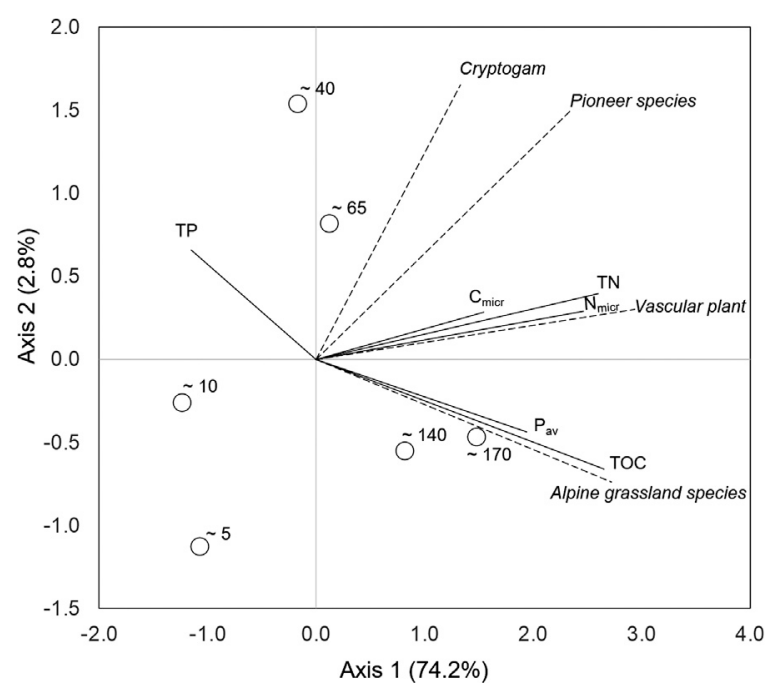

FIGURE 7 | RDA ordination bi-plot showing the distribution of the six chronosequence stages (represented by the centroids of the three replicates per stage) and the relationships between soil properties (solid lines) and vegetation covers (dashed lines). TOC, total organic carbon; TN, total nitrogen; $\mathrm{C}_{\text {micr }}$, microbial carbon; $\mathrm{N}_{\text {micr }}$, microbial nitrogen; $\mathrm{TP}$, total phosphorus; $\mathrm{P}_{\mathrm{av}}$, bicarbonate extractable (available) phosphorus. The variance explained by each axes is provided in brackets.

increase in species richness, the vegetation cover was very scarce even after 170 years since deglaciation. At the last stage of the chronosequence, cryptogams and vascular plants indeed occupied only $34 \%$ of the surface, while Schumann et al. (2016) recorded mean vegetation cover values of $70 \%$ in 123 years-old stages from 16 proglacial forelands in the Alps (located between 2000 and 2,600 $\mathrm{m}$ a.s.l.). This difference may be related to the complete absence of trees and shrubs within and around Lauson foreland, which is far above the treeline.

The dynamics observed for pioneer and alpine grassland species were confirmed by the population structure of the two target species, Saxifraga and Silene. In particular, Saxifraga showed a typical pioneer behavior, spreading over the study area since the very first stages of the chronosequence and drastically reducing its cover after 65 years, while the more nutrient-demanding Silene firmly established only after (40-) 65 years of ice-free development, indicating a complementary successional pattern. Nevertheless, both species showed an uneven-aged demographic structure, with higher frequencies in the smallest diameter classes and lower frequencies in the largest ones. Saxifraga and Silene seem indeed to perform ruderal strategies (Grime, 2006), which implies a great amount of seed production, resulting in the abundance of seedlings and showing fast-colonization ability, rather than a stress tolerant behavior, as it can be expected in extreme environments such as glacier forelands. The results obtained by our demographic approach, indicating a huge investment in plant reproduction, align with the findings of many authors in proglacial environments, where ruderal strategies allow for plant colonization in the early successional stages (Tscherko et al., 2005; Caccianiga et al., 2006; Gobbi et al., 2010; Erschbamer and Caccianiga, 2016).
Frequency variations in diameter classes were statistically significant for both species throughout the entire chronosequence even if a complete transformation of the demographic structure, from uneven-to even-aged, was not reached in the Lauson glacier foreland.

A clear pattern of a primary succession was observed in both functional species pool dynamics and target species population structure, with an increase in alpine grassland species number and cover over time, and a simultaneous decline in pioneer species. Overall, considering the limited vegetation cover and the partial plant community substitution among successional stages, the Lauson chronosequence time span (170 years) was not sufficient for the establishment of a stable alpine grassland climax community (highlighted also by the Silene demographic structure), supporting the 500 years-minimum age required for Carex curvula All. climax type stated by Andreis et al. (2001).

Although all soils found in the Lauson glacier foreland referred to the WRB group of Regosols, we observed clear soil-forming processes such as a weak mineral weathering (evidenced by the $\mathrm{Fe}_{\mathrm{o}}$ and $\mathrm{Fe}_{\mathrm{d}}$ values) and leaching processes (evidenced by $\mathrm{pH}$ and SATB decrease), mostly guided by the soil organic matter buildup with time since deglaciation. The decline observed in $\mathrm{pH}$ followed the typical pattern of the proglacial chronosequences (Messer, 1988; Frenot et al., 1998; Anderson et al., 2000); it was however much slower than in proglacial areas located at lower elevations (e.g., D'Amico et al., 2014), in which the overall ecosystem productivity was enhanced by higher temperatures and the larger input of plant litter accelerates soil acidification. In our study, soil $\mathrm{pH}$ was very high in the recently exposed sediments. As no carbonates were detected, the high $\mathrm{pH}$ was probably related to the initial weathering of silicates, which could lead to a release of base cations, able to increase $\mathrm{pH}$ values in very coarse-grained soils. In young ice-free till (ca. 5-10 years from deglaciation), not yet vegetated, these processes can lead to very high $\mathrm{pH}$ values because of the lack of colloidal buffer surfaces, as deduced by the very low clay content $(<2 \%)$ and the related scarce cation exchange capacity $\left(\max 2 \mathrm{cmol}_{(+)} \mathrm{kg}^{-1}\right.$ in CA horizon in the 5 years old material) (Celi et al., 2013). Moreover, the influence of seasonal glacial runoff cannot be excluded, possibly bringing high $\mathrm{Ca}$ and $\mathrm{K}$ loads, regardless of bedrock (Anderson et al., 1997, 2000) and thus increasing soil pH. High concentrations of $\mathrm{K}$ in glacial melt waters, derived from leaching of interlayer cations from biotite, were observed in many works (Drever and Hurcomb, 1986; Stallard, 1995). However, soil acidification occurred over time, likely induced by the increasing vegetation cover and the related release of carboxylic acids through root exudates and/or acidic compounds formed during organic matter decomposition, as well as by organic acids released by bacteria and fungi (Brunner et al., 2011). The leaching of base cations, due to the lack of exchanging surfaces, could contribute as well to the $\mathrm{pH}$ decrease (Burt and Alexander, 1996; Darmody et al., 2005; Bernasconi et al., 2011).

In addition to climatic stress such as drought, frost and cryoturbation, nutrient limitation plays a fundamental role in controlling plant establishment and emphasizes the role of safesites (sensu Harper et al., 1961), where water fluxes increase 
moisture and nutrient accumulation, enabling the vegetation to survive. Glacial runoff, which represents an important input of nutrients and base cations, could have facilitated the uptake by the early-successional species such as Saxifraga, despite the very harsh substrate of the recently deglaciated debris (Göransson et al., 2016). In the Lauson foreland, we indeed found an optimal base saturation for plant establishment in the first 40 years since deglaciation, with $\mathrm{Ca}: \mathrm{Mg}: \mathrm{K}$ stoichiometric ratios suitable for plant nutrition. Despite the decreasing $\mathrm{pH}$ along the terrain age gradient, cation-exchange capacity (CEC) raised, likely as a consequence of organic matter accumulation rather than formation of secondary minerals having higher CEC compared to the unweathered parent material (Bernasconi et al., 2011).

Total nitrogen levels were extremely low and were detectable only in the more organic matter-rich and developed upper horizons. This result highlighted that $\mathrm{N}$ was one of the major limiting factors of the Lauson soil-vegetation system due to the lack of N-fixing plants (Körner, 2003; Göransson et al., 2016) and to a possible, moderate contribution of $\mathrm{N}$-fixing free-living microbes (Duc et al., 2009). Göransson et al. (2016), in the wetter Damma proglacial chronosequence in Switzerland, found an exponential increasing trend of $\mathrm{TN}$ during the first 137 years of soil development and argued that the main $\mathrm{N}$ input was probably due to atmospheric deposition (assumed to be approximately $5-10 \mathrm{~kg} \cdot \mathrm{ha}^{-1} \cdot \mathrm{yr}^{-1}$ ). Although in nearby areas (Indren Glacier, Lys Valley, Monte Rosa Group), the atmospheric $\mathrm{N}$ deposition was similar, being $6.6 \mathrm{~kg} \cdot \mathrm{ha}^{-1} \cdot \mathrm{yr}^{-1}$ in the last few years (Colombo et al., 2019), the smaller $\mathrm{N}$ inputs in our soils were associated with lower mean yearly precipitation because of the isolated position of the Lauson proglacial area, surrounded by high mountains. Thus, our findings suggest that in the Lauson foreland, similarly to areas with low N-deposition like Glacier Bay in Alaska or Franz Josef Glacier in New Zealand (Chapin et al., 1994; Menge and Hedin, 2009), the role of atmospheric deposition was less important in $\mathrm{N}$ cycling. Furthermore, Göransson et al. (2016) found, particularly at early stages, that $\mathrm{N}$ inputs exceeded plant uptake, and low $\mathrm{P}$ levels limited plant colonization more than low $\mathrm{N}$ levels. In the entire Lauson chronosequence, soil TP contents ranged between 600 and $700 \mathrm{mg} \cdot \mathrm{kg}^{-1}$, which represent a favourable range for $\mathrm{P}$ cycling and plant establishment (Yang et al., 2013). With time, the release of protons and carboxylic acids caused the dissolution of P-bearing minerals, slightly contributing to feed the available $\mathrm{P}$ pool and then plant uptake (Celi et al., 2013). In the older, more structured, and more functional soils, with increased cover of alpine grassland species, $\mathrm{P}$ biocycling became particularly evident. Particularly at the fourth and sixth stages of the chronosequence, the upper soil horizons became enriched in TP content. This depth trend can be attributed to plant root exploration and uplift of $\mathrm{P}$ from the deeper soil horizons to the surface, through deposition of plant residues. However, compared to other proglacial chronosequences in the Alps, with similar time span, the pedogenic processes remained at an incipient stage, likely because of the lower biomass inputs (D'Amico et al., 2014): the cold temperatures characterizing the Lauson forefield and the associated processes (i.e. short growing season, cryoturbation, root damages and slow decomposition rates) slow down plant colonization, which in turn reduces TOC accumulation and $\mathrm{N}$ availability; the low $\mathrm{N}$ availability, in a low- $\mathrm{N}$ deposition site, in turn, slows down plant colonization, creating a negative feedback which inhibits ecosystem development.

The present study provided novel information concerning the differing function of pioneer and late-successional herbaceous species in affecting soil biogeochemistry in recently deglaciated debris. Indeed, the comparison among soils sampled under plants (SaxS and SilS) and non-vegetated soils (BareS) highlighted the pivotal role of vegetation in soil development and nutrient mobilization, along the whole chronosequence, from the very early stages to the latest ones. Silene performed a greater soil conditioning than Saxifraga in terms of TOC and TN accumulation and development of microbial biomass even within the early stage time points of soil development where both plant species occurred. This may be due to the different growth forms of the two target species, as the cushion species Silene may exert more enhancing effects on soil formation than the prostrate species Saxifraga (Bonanomi et al., 2016). The drastic decline of Saxifraga after 65 years in the chronosequence, likely induced by the competition with more nutrient-demanding species, suggested a facilitation process for the establishment of other plants, linked to the several microsites enriched in organic matter and nutrients. After 140 years, soil development and functionality are proved by higher TOC contents in BareS, as a result of organic matter translocation and mixing processes, which led to even higher concentrations than those in SaxS after 65 years. Microbial and fungal processes could have contributed to this TOC and N enrichment as well. Nitrogen content increased significantly in BareS with time, as observed also in soil pit horizons. Nonetheless, unlike processes involving organic matter, TN resulted in very low concentrations even in the oldest stages, representing the major limiting factor for more nutrient-demanding plant species. Where measurable, the TOC:TN ratio was between 8 and 17.5, thus in the normal range for high-altitude grassland and tundra soils (e.g., D'Amico et al., 2014, 2015). The increase in both microbial $\mathrm{C}$ and $\mathrm{N}$ associated to the target species (and more generally to vascular species cover) along the chronosequence proved again the strong biotic impact in nutrient accumulation compared to abiotic processes, such as atmospheric deposition. In particular, the enhanced microbial biomass and activity associated to the increased concentration of $\mathrm{C}$ and $\mathrm{N}$ under the target species may have exerted a positive impact on enzyme activity and therefore on microbial $\mathrm{N}$ fixation. Similarly, available $\mathrm{P}$ content in BareS was very low, but both target species enhanced its concentration along the chronosequence confirming the priming effect of vegetation on $\mathrm{P}$ biocycling.

In the youngest stages (ca. 5-10 years since deglaciation) the observed accumulation of $\mathrm{P}$ in Saxifraga tissues was probably a consequence of $\mathrm{N}$ limitation: under drastic limiting conditions the accumulation of nutrients in tissues has been demonstrated as a possible plant physiological response (Simon et al., 2017). This may be further confirmed by the quite high C:N ratio in the herbaceous tissues, especially for Silene (Hobbie et al., 1998). In older stages, where organic matter and $\mathrm{N}$ became more abundant, 
$\mathrm{P}$ content in Saxifraga tissues fell to more typical values (Richardson et al., 2004). However, N:P in plant tissues was very low, along the whole chronosequence, and far from the value of 12 , a threshold beyond which plant development is P-limited, such as in highly developed soils (Wardle, 2004) or in particular P-limited systems. For instance, in the Damma proglacial chronosequence $(\mathrm{N}: \mathrm{P}$ ratios in the aboveground vegetation $>19$, Göransson et al., 2016) the main P-containing mineral was the slowly weathering fluoroapatite (Bernasconi et al., 2011), while the Verra Grande forefield (D'Amico et al., 2020b) developed on serpentinite and almost devoid of P-bearing minerals.

\section{CONCLUSION}

This work provided novel results on individual plant species trajectories and related soil development through successional stages of a proglacial chronosequence. Despite the extreme conditions for plant establishment, the Lauson proglacial foreland allowed a remarkable early (5-10 years) and speciesrich colonization, attained by pioneer species in the available safe micro-sites. Carbon seemed to be the major constraint to microbial development together with $\mathrm{N}$, which also hampered plant colonization. However, nutrient requirements for pioneer plants were met, likely thanks to the water fluxes funnelled between rocks. The alpine grassland species colonization started indeed immediately, although species number and cover pronouncedly increased only when the soil reached sufficient nutrient supply and functionality. Then, after about one century of ecosystem development since deglaciation, soil conditions appear suitable for the establishment of more competitive vegetation, typical of alpine grassland communities. Nonetheless, the improving effect on soil triggered by $S$. oppositifolia was already evident on quasi-inert substrates, free from ice for a limited time, highlighting the relevant role of biotic factors in stimulating the initial phases of soil formation. However, more biomass-productive species,

\section{REFERENCES}

Aeschimann, D., Lauber, K., and André Michel, D. (2004). Flora alpina: atlante delle 4500 piante vascolari delle Alpi. Bologna: Zanichelli.

Anderson, S. P., Drever, J. I., Frost, C. D., and Holden, P. (2000). Chemical weathering in the foreland of a retreating glacier. Geochem. Cosmochim. Acta. 64, 1173-1189. doi:10.1016/S0016-7037(99)00358-0

Anderson, S. P., Drever, J. I., and Humphrey, N. F. (1997). Chemical weathering in glacial environments. Geology. 25 (5), 399-402. doi:10.1130/0091-7613(1997) 025<0399:CWIGE $>2.3 . \mathrm{CO} ; 2$

Andreis, C., Caccianiga, M., and Cerabolini, B. (2001). Vegetation and environmental factors during primary succession on glacier forelands: some outlines from the Italian Alps. Plant Biosyst.-Int. J. Deal. Asp. Plant Biol. 135, 295-310. doi:10.1080/11263500112331350930

Bartolucci, F., Peruzzi, L., Galasso, G., Albano, A., Alessandrini, A., Ardenghi, N., et al. (2018). An updated checklist of the vascular flora native to Italy. Plant Biosyst.- Int. J. Deal. Asp. Plant Biol. 152, 179-303. doi:10.1080/11263504.2017. 1419996 such as $S$. acaulis, performed a greater soil conditioning than S. oppositifolia, even within the early stage time points where both plants were present, becoming progressively more expressed with time. Therefore, C:N:P stoichiometry in proglacial areas is plantinfluenced, and the impact on nutrient dynamics is related to functional species pool, with a major role played by latesuccessional grassland species.

\section{DATA AVAILABILITY STATEMENT}

The datasets presented in this study can be found in online repositories. The names of the repository/repositories and accession number(s) can be found below: 10.5281/zenodo. 4067891.

\section{AUTHOR CONTRIBUTIONS}

Conceptualization: ML and LC; Methodology: ML and LC; Formal analysis and investigation: AM, MD'A, MP, EQ, SR, LC, and ML; Writing-original draft preparation: AM, MD'A, MP, EQ, SE, LC, and ML; Funding acquisition: ML and LC; Supervision: ML and LC.

\section{FUNDING}

The project was funded by Gran Paradiso National Park.

\section{ACKNOWLEDGMENTS}

We are thankful to the whole Gran Paradiso National Park for technical assistance and particularly to Laura Poggio for her role in promoting this research. We are grateful to Cristina Lerda, Marco Prati, and Elena Zanzo for laboratory support.

Benedict, J. B. (1989). Use of Silene acaulis for dating: the relationship of cushion diameter to age. Arct. Alp. Res. 21, 91. doi:10.2307/1551520

Bernasconi, S. M., Bauder, A., Bourdon, B., Brunner, I., Bünemann, E., Chris, I., et al. (2011). Chemical and biological gradients along the Damma glacier soil chronosequence, Switzerland. Vadose Zone J. 10, 867-883. doi:10.2136/vzj2010. 0129

Bonanomi, G., Stinca, A., Chirico, G. B., Ciaschetti, G., Saracino, A., and Incerti, G. (2016). Cushion plant morphology controls biogenic capability and facilitation effects of Silene acaulis along an elevation gradient. Funct. Ecol. 30, 1216-1226. doi:10.1111/1365-2435.12596

Bowman, R. (1988). A rapid method to determine total phosphorus in soils. Soil Sci. Soc. Am. J. 52, 1301-1304.

Braun-Blanquet, J. (1932). Plant sociology, the study of plant communities. 1st Edn. New York: McGraw-Hill book company, inc.

Brookes, P., Landman, A., Pruden, G., and Jenkinson, D. (1985). Chloroform fumigation and the release of soil nitrogen: a rapid direct extraction method to measure microbial biomass nitrogen in soil. Soil Biol. Biochem. 17, 837-842.

Brunner, I., Plötze, M., Rieder, S., Zumsteg, A., Furrer, G., and Frey, B. (2011). Pioneering fungi from the Damma glacier forefield in the Swiss Alps can 
promote granite weathering. Geobiology 9, 266-279. doi:10.1111/j.1472-4669. 2011.00274.x

Burga, C. A., Krüsi, B., Egli, M., Wernli, M., Elsener, S., Ziefle, M., et al. (2010). Plant succession and soil development on the foreland of the Morteratsch glacier (Pontresina, Switzerland): straight forward or chaotic? Flora-Morphol. Distrib. Funct. Ecol. Plants. 205, 561-576. doi:10.1016/j.flora.2009.10.001

Burt, R., and Alexander, E. B. (1996). Soil development on moraines of Mendenhall Glacier, southeast Alaska. 2. Chemical transformations and soil micromorphology. Geoderma. 72, 19-36. doi:10.1016/0016-7061(96)00022-5

Caccianiga, M., and Andreis, C. (2004). Pioneer herbaceous vegetation on glacier forelands in the Italian Alps. Phytocoenologia 34, 55-89. doi:10.1127/0340269X/2004/0034-0055

Caccianiga, M., Luzzaro, A., Pierce, S., Ceriani, R. M., and Cerabolini, B. (2006). The functional basis of a primary succession resolved by CSR classification. Oikos. 112, 10-20. doi:10.1111/j.0030-1299.2006.14107.x

Cannone, N., Diolaiuti, G., Guglielmin, M., and Smiraglia, C. (2008). Accelerating climate change impacts on alpine glacier forefield ecosystems in the European Alps. Ecol. Appl. 18, 637-648. doi:10.1890/07-1188.1

Celi, L., Cerli, C., Turner, B. L., Santoni, S., and Bonifacio, E. (2013). Biogeochemical cycling of soil phosphorus during natural revegetation of Pinus sylvestris on disused sand quarries in Northwestern Russia. Plant Soil. 367, 121-134. doi:10.1007/s11104-013-1627-y

Chapin, F. S., Walker, L. R., Fastie, C. L., and Sharman, L. C. (1994). Mechanisms of primary succession following deglaciation at Glacier Bay, Alaska. Ecol. Monogr. 64, 149-175. doi:10.2307/2937039

Chapman, H. (1965). Cation-exchange capacity. Methods Soil Anal. Part 2 Chem. Microbiol. Prop. 9, 891-901.

Colombo, N., Bocchiola, D., Martin, M., Confortola, G., Salerno, F., Godone, D., et al. (2019). High export of nitrogen and dissolved organic carbon from an Alpine glacier (Indren Glacier, NW Italian Alps). Aquat. Sci. 81, 74. doi:10. 1007/s00027-019-0670-z

Crooke, W., and Simpson, W. (1971). Determination of ammonium in Kjeldahl digests of crops by an automated procedure. J. Sci. Food Agric. 22, 9-10.

Cucu, M. A., Said-Pullicino, D., Maurino, V., Bonifacio, E., Romani, M., and Celi, L. (2014). Influence of redox conditions and rice straw incorporation on nitrogen availability in fertilized paddy soils. Biol. Fertil. Soils. 50, 755-764. doi:10.1007/ s00374-013-0893-4

Daget, P., and Poissonet, J. (1971). Une méthode d'analyse phytologique des prairies. Critères d'application. Annales Agronomes 22, 5-41.

Darmody, R. G., Allen, C. E., and Thorn, C. E. (2005). Soil topochronosequences at storbreen, jotunheimen, Norway. Soil Sci. Soc. Am. J. 69, 1275-1287. doi:10. 2136/sssaj2004.0204

Drever, J. I., and Hurcomb, D. R. (1986). Neutralization of atmospheric acidity by chemical weathering in an alpine drainage basin in the North Cascade Mountains. Geology. 14, 221-224.

Duc, L., Noll, M., Meier, B. E., Bürgmann, H., and Zeyer, J. (2009). High diversity of diazotrophs in the forefield of a receding alpine glacier. Microb. Ecol. 57, 179-190. doi:10.1007/s00248-008-9408-5

Dümig, A., Smittenberg, R., and Kögel-Knabner, I. (2011). Concurrent evolution of organic and mineral components during initial soil development after retreat of the Damma glacier, Switzerland. Geoderma. 163, 83-94. doi:10.1016/j. geoderma.2011.04.006

Dyurgerov, M. B., and Meier, M. F. (2000). Twentieth century climate change: evidence from small glaciers. Proc. Natl. Acad. Sci. U.S.A. 97, 1406-1411. doi:10. 1073/pnas.97.4.1406

D’Amico, M. E., Freppaz, M., Filippa, G., and Zanini, E. (2014). Vegetation influence on soil formation rate in a proglacial chronosequence (Lys Glacier, NW Italian Alps). Catena. 113, 122-137. doi:10.1016/j.catena.2013. 10.001

D’Amico, M., Gorra, R., and Freppaz, M. (2015). Small-scale variability of soil properties and soil-vegetation relationships in patterned ground on different lithologies (NW Italian Alps). Catena. 135, 47-58. doi:10.1016/j.catena.2015. 07.005

D’Amico, M. E., Pintaldi, E., Sapino, E., Colombo, N., Quaglino, E., Stanchi, S., et al. (2020a). Soil types of Aosta Valley (NW-Italy). J. Maps. 16 (2), 755-765. doi:10. 1080/17445647.2020.1821803

D’Amico, M., Almeida, J. P., Barbieri, S., Castelli, F., Sgura, E., Sineo, G., et al. (2020b). Ectomycorrhizal utilization of different phosphorus sources in a glacier forefront in the Italian Alps. Plant Soil. 446, 81-95. doi:10.1007/ s11104-019-04342-0

Egli, M., Fitze, P., and Mirabella, A. (2001). Weathering and evolution of soils formed on granitic, glacial deposits: results from chronosequences of Swiss alpine environments. Catena. 45, 19-47. doi:10.1016/S0341-8162(01) 00138-2

Egli, M., Wernli, M., Kneisel, C., Biegger, S., and Haeberli, W. (2006). Melting glaciers and soil development in the proglacial area Morteratsch (Swiss Alps): II. Modeling the present and future soil state. Arctic Antarct. Alpine Res. 38, 510-521. doi:10.1657/1523-0430(2006)38[510:mgasdi]2.0.co;2

Egli, M., Mavris, C., Mirabella, A., and Giaccai, D. (2010). Soil organic matter formation along a chronosequence in the Morteratsch proglacial area (Upper Engadine, Switzerland). Catena. 82, 61-69. doi:10.1016/j.catena.2010.05.001

Eichel, J. (2019). "Vegetation succession and biogeomorphic interactions in glacier forelands," in Geomorphology of proglacial systems Geography of the physical environment. Editors T. Heckmann and D. Morche (Cham: Springer International Publishing), 327-349. doi:10.1007/978-3-319-94184-4_19

Erschbamer, B., and Caccianiga, M. S. (2016). "Glacier forelands: lessons of plant population and community development," in Progress in botany. Editors F. M. Cánovas, U. Lüttge, and R. Matyssek (Cham, Switzerland: Springer International Publishing), 78, 259-284. doi:10.1007/124_2016_4

FAO (2006). Guidelines for soil description. Fourth Edition. Rome: FAOWorld Soil Resour. Rep., 103.

Frenot, Y., Gloaguen, J. C., Cannavacciuolo, M., and Bellido, A. (1998). Primary succession on glacier forelands in the subantarctic Kerguelen Islands. J. Veg. Sci. 9, 75-84. doi:10.2307/3237225

Gobbi, M., Caccianiga, M., Cerabolini, B., Bernardi, F., Luzzaro, A., and Pierce, S. (2010). Plant adaptive responses during primary succession are associated with functional adaptations in ground beetles on deglaciated terrain. Community Ecol. 11, 223-231. doi:10.1556/ComEc.11.2010.2.11

Göransson, H., Welc, M., Bünemann, E. K., Christl, I., and Venterink, H. O. (2016). Nitrogen and phosphorus availability at early stages of soil development in the Damma glacier forefield, Switzerland; implications for establishment of N2fixing plants. Plant Soil. 404, 251-261. doi:10.1007/s11104-016-2821-5

Grime, J. P. (2006). Plant strategies, vegetation processes, and ecosystem properties. Hoboken, NJ: John Wiley \& Sons.

Hammer, Ø., Harper, D. A., and Ryan, P. D. (2001). PAST: paleontological statistics software package for education and data analysis. Palaeontol. Electron. 4, 9.

Harper, J. L., Clatworthy, J. N., McNaughton, I. H., and Sagar, G. R. (1961). The evolution and ecology of closely related species living in the same area. Evolution. 15, 209-227. doi:10.1111/j.1558-5646.1961.tb03144.x

Hobbie, E. A., Macko, S. A., and Shugart, H. H. (1998). Patterns in N dynamics and $\mathrm{N}$ isotopes during primary succession in Glacier Bay, Alaska. Chem. Geol. 152, 3-11. doi:10.1016/S0009-2541(98)00092-8

IUSS Working Group WRB (2015). World reference base for soil resources 2014, update 2015: international soil classification system for naming soils and creating legends for soil maps. World Soil Resour. Rep. No. 106, 192

Jones, C. C., and del Moral, R. (2009). Dispersal and establishment both limit colonization during primary succession on a glacier foreland. Plant Ecol. 204, 217-230. doi:10.1007/s11258-009-9586-3

Jumpponen, A., Brown, S. P., Trappe, J. M., Cázares, E., and Strömmer, R. (2012). Twenty years of research on fungal-plant interactions on Lyman Glacier forefront - lessons learned and questions yet unanswered. Fungal Ecol. 5, 430-442. doi:10.1016/j.funeco.2012.01.002

Körner, C. (2003). Alpine plant life: functional plant ecology of high mountain ecosystems; with 47 tables. Berlin, Germany: Springer Science \& Business Media

Le Bayon, B., and Ballevre, M. (2006). Deformation history of a subducted continental crust (Gran Paradiso, Western Alps): continuing crustal shortening during exhumation. J. Struct. Geol. 28, 793-815. doi:10.1016/j.jsg. 2006.02.009

Magurran, A. E. (1988). Ecological diversity and its measurement. Princeton, NJ: Princeton University Press

Matthews, J. A. (1999). Disturbance regimes and ecosystem response on recentlydeglaciated substrates. Ecosyst. World. 17-38.

Matthews, J. A. (1992). The ecology of recently-deglaciated terrain: a geoecological approach to glacier forelands. Cambridge, United Kingdom: Cambridge University Press. 
Matthews, J. A., and Vater, A. E. (2015). Pioneer zone geo-ecological change: observations from a chronosequence on the Storbreen glacier foreland, Jotunheimen, southern Norway. Catena. 135, 219-230. doi:10.1016/j.catena. 2015.07.016

Mavris, C., Egli, M., Plötze, M., Blum, J. D., Mirabella, A., Giaccai, D., et al. (2010). Initial stages of weathering and soil formation in the Morteratsch proglacial area (Upper Engadine, Switzerland). Geoderma. 155, 359-371. doi:10.1016/j. geoderma.2009.12.019

Mehra, O., and Jackson, M. (2013). "Iron oxide removal from soils and clays by a dithionite-citrate system buffered with sodium bicarbonate," in Clays and clay minerals. (Amsterdam, Netherlands: Elsevier), 317-327.

Menge, D. N. L., and Hedin, L. O. (2009). Nitrogen fixation in different biogeochemical niches along a 120 000-year chronosequence in New Zealand. Ecology. 90, 2190-2201. doi:10.1890/08-0877.1

Mercalli, L., and Berro, D. C. (2003). Atlante climatico della Valle d'Aosta. Torino, Italy: Edizioni Società Meteorologica Subalpina.

Messer, A. C. (1988). Regional variations in rates of pedogenesis and the influence of climatic factors on moraine chronosequences, southern Norway. Arct. Alp. Res. 20, 31-39. doi:10.2307/1551696

Moris, J. V., Vacchiano, G., Enri, S. R., Lonati, M., Motta, R., and Ascoli, D. (2017). Resilience of European larch (Larix decidua Mill.) forests to wildfires in the western Alps. New For. 48, 663-683. doi:10.1007/s11056-017-9591-7

Nemergut, D. R., Anderson, S. P., Cleveland, C. C., Martin, A. P., Miller, A. E., Seimon, A., et al. (2007). Microbial community succession in an unvegetated, recently deglaciated soil. Microb. Ecol. 53, 110-122. doi:10.1007/s00248-006-9144-7

Olsen, S. R. (1954). Estimation of available phosphorus in soils by extraction with sodium bicarbonate. Washington, DC: US Department of Agriculture.

Paul, F., Kääb, A., Maisch, M., Kellenberger, T., and Haeberli, W. (2004). Rapid disintegration of Alpine glaciers observed with satellite data. Geophys. Res. Lett. 31 (21). doi:10.1029/2004GL020816

Pecher, C., Tasser, E., and Tappeiner, U. (2011). Definition of the potential treeline in the European Alps and its benefit for sustainability monitoring. Ecol. Indicat. 11, 438-447. doi:10.1016/j.ecolind.2010.06.015

Perotti, E., Probo, M., Pittarello, M., Lonati, M., and Lombardi, G. (2018). A 5-year rotational grazing changes the botanical composition of sub-alpine and alpine grasslands. Appl. Veg. Sci. 21, 647-657. doi:10.1111/avsc.12389

Pickett, S. T. (1989). "Space-for-time substitution as an alternative to long-term studies," in Long-term studies in ecology. (Berlin, Germany: Springer), 110-135

Pittarello, M., Probo, M., Lonati, M., and Lombardi, G. (2016). Restoration of subalpine shrub-encroached grasslands through pastoral practices: effects on vegetation structure and botanical composition. Appl. Veg. Sci. 19, 381-390. doi:10.1111/avsc.12222

Pörtner, H., Roberts, D., Masson-Delmotte, V., Zhai, P., Tignor, M., Poloczanska, E., et al. (2019). IPCC special report on the ocean and cryosphere in a changing Q20 climate. Geneva, Switzerland: IPCC.

Raffl, C., Mallaun, M., Mayer, R., and Erschbamer, B. (2006). Vegetation succession pattern and diversity changes in a glacier valley, central Alps, Austria. Arctic Antarct. Alpine Res. 38, 421-428. doi:10.1657/1523-0430(2006)38[421:VSPADC]2.0.CO;2

Richardson, S. J., Peltzer, D. A., Allen, R. B., McGlone, M. S., and Parfitt, R. L. (2004). Rapid development of phosphorus limitation in temperate rainforest along the Franz Josef soil chronosequence. Oecologia. 139, 267-276. doi:10. 1007/s00442-004-1501-y

Sardans, J., Rivas-Ubach, A., and Peñuelas, J. (2012). The C:N:P stoichiometry of organisms and ecosystems in a changing world: a review and perspectives. Perspect. Plant Ecol. Evol. Systemat. 14, 33-47. doi:10.1016/j.ppees.2011.08.002

Schumann, K., Gewolf, S., and Tackenberg, O. (2016). Factors affecting primary succession of glacier foreland vegetation in the European Alps. Alpine Bot. 126, 105-117. doi:10.1007/s00035-016-0166-6

Schwertmann, U. (1964). The differentiation of iron oxide in soils by a photochemical extraction with acid ammonium oxalate. Z. Für Pflanzenernähr. Bodenkd 105, 194-201.
Simon, J., Dannenmann, M., Pena, R., Gessler, A., and Rennenberg, H. (2017). Nitrogen nutrition of beech forests in a changing climate: importance of plantsoil-microbe water, carbon, and nitrogen interactions. Plant Soil. 418, 89-114. doi:10.1007/s11104-017-3293-y

Sistema delle Conoscenze Territoriali: Geoportale Regione Autonoma Valle d'Aosta. Catasto Regionale Ghiacciai [Regional Glacier Land Register]. Available at: http://www.geoportale.regione.vda.it/ (Accessed February 10, 2020).

Smiraglia, C., and Diolaiuti, G. (2015). Il nuovo catasto dei ghiacciai italiani. Bergamo, Italy: Ev-K2-CNR Bergamo Publ, 134-138.

SPSS (2016). IBM SPSS statistics, release, 24. Armonk, NY: Somers NY IBM Corp

Stallard, R. F. (1995). Tectonic, environmental, and human aspects of weathering erosion: a Global Eeview using a Steady-State Perspective. Annu. Rev. Earth Planet Sci. 23, 11-39.

Stöcklin, J., and Bäumler, E. (1996). Seed rain, seedling establishment and clonal growth strategies on a glacier foreland. J. Veg. Sci. 7, 45-56. doi:10.2307/ 3236415

Tasser, E., and Tappeiner, U. (2005). New model to predict rooting in diverse plant community compositions. Ecol. Model. 185, 195-211. doi:10.1016/j.ecolmodel. 2004.11.024

Ter Braak, C. J. F., and Smilauer, P. (1998). CANOCO reference manual and user's guide to Canoco for windows: software for canonical community ordination, version 4. Wageningen: Centre for Biometry, 351.

Tscherko, D., Hammesfahr, U., Zeltner, G., Kandeler, E., and Böcker, R. (2005). Plant succession and rhizosphere microbial communities in a recently deglaciated alpine terrain. Basic Appl. Ecol. 6, 367-383. doi:10.1016/j.baae. 2005.02.004

Těšitel, J., Těšitelová, T., Bernardová, A., Drdová, E. J., Lučanová, M., and Klimešová, J. (2014). Demographic population structure and fungal associations of plants colonizing High Arctic glacier forelands, Petuniabukta, Svalbard. Polar Res. 33, 20797. doi:10.3402/polar.v33.20797

Vitousek, P. M., Aber, J. D., Howarth, R. W., Likens, G. E., Matson, P. A., Schindler, D. W., et al. (1997). Human alteration of the global nitrogen cycle: sources and consequences. Ecol. Appl. 7, 737-750. doi:10.1890/1051-0761(1997)007[0737: HAOTGN]2.0.CO;2

Walker, L. R., and del Moral, R. (2003). Primary succession and ecosystem rehabilitation. 1st Edn. Cambridge, United Kingdom: Cambridge University Press. doi:10.1017/CBO9780511615078

Wardle, D. A. (2004). Ecosystem properties and forest decline in contrasting longterm chronosequences. Science 305, 509-513. doi:10.1126/science.1098778

Yang, X., Post, W. M., Thornton, P. E., and Jain, A. (2013). The distribution of soil phosphorus for global biogeochemical modeling. Biogeosciences 10, 2525-2537. doi:10.5194/bg-10-2525-2013

Zhang, Y., Chen, L., and Wang, M. (2018). Linkages of C: N: P stoichiometry between soil and leaf and their response to climatic factors along altitudinal gradients. J. Soils Sediments 19, 1820-1829. doi:10.1007/s11368-018-2173-2

Zemp, M., Haeberli, W., Hoelzle, M., and Paul, F. (2006). Alpine glaciers to disappear within decades? Geophys. Res. Lett. 33, L13504. doi:10.1029/ 2006GL026319

Conflict of Interest: The authors declare that the research was conducted in the absence of any commercial or financial relationships that could be construed as a potential conflict of interest.

Copyright (c) 2021 Mainetti, D’Amico, Probo, Quaglia, Ravetto Enri, Celi and Lonati. This is an open-access article distributed under the terms of the Creative Commons Attribution License (CC BY). The use, distribution or reproduction in other forums is permitted, provided the original author(s) and the copyright owner(s) are credited and that the original publication in this journal is cited, in accordance with accepted academic practice. No use, distribution or reproduction is permitted which does not comply with these terms. 